
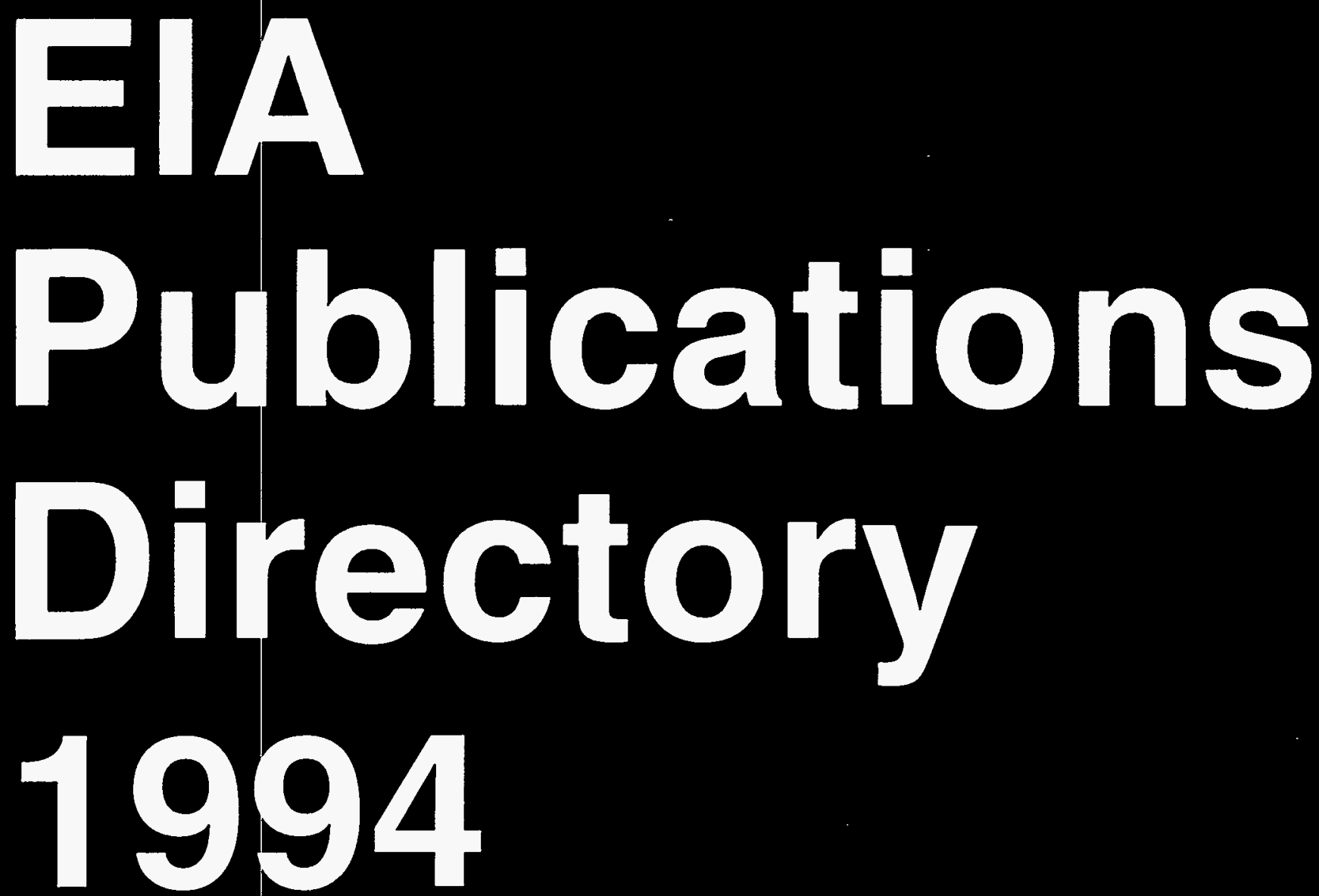

July 1995

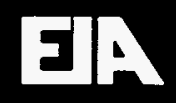

Energy Information Administration 
This publication is available free of charge from the National Energy Information Center at the following address:

National Energy Information Center, EI-231

Energy Information Administration

Forrestal Building, Room 1F-048

Washington, DC 20585

(202) 586-8800

Telecommunications Device for People Who Are Deaf or Hard of Hearing (TTY): (202) 586-1181

9 a.m. to 5 p.m., eastern time, M-F 


\section{DISCLAIMER}

This report was prepared as an account of work sponsored by an agency of the United States Government. Neither the United States Government nor any agency thereof, nor any of their employees, make any warranty, express or implied, or assumes any legal liability or responsibility for the accuracy, completeness, or usefulness of any information, apparatus, product, or process disclosed, or represents that its use would not infringe privately owned rights. Reference herein to any specific commercial product, process, or service by trade name, trademark, manufacturer, or otherwise does not necessarily constitute or imply its endorsement, recommendation, or favoring by the United States Government or any agency thereof. The views and opinions of authors expressed herein do not necessarily state or reflect those of the United States Government or any agency thereof. 


\section{DISCLAIMER}

Portions of this document may be illegible in electronic image products. Images are produced from the best available original document. 
DOE/EIA-0149(94)

Distribution Category UC-950

\title{
EIA Publications Directory 1994
}

\author{
July 1995
}

Energy Information Administration

National Energy Information Center

U.S. Department of Energy

Washington, DC 20585

This report was prepared by the Energy Information Administration, the independent statistical and analytical agency within the Department of Energy. The information contained herein should not be construed as advocating or reflecting any policy position of the Department of Energy or any other organization. 


\section{Preface}

Enacted in 1977, the Department of Energy (DOE) Organization Act established the Energy Information Administration (EIA) as the Department's independent statistical and analytical agency, with a mandate to collect and publish data and prepare analyses on energy production, consumption, prices, resources, and projections of energy supply and demand. This edition of the EIA Publications Directory contains titles and abstracts of periodicals and one-time reports produced by EIA from January through December 1994.
The body of the Directory contains citations and abstracts arranged by broad subject categories: metadata, coal, oil and gas, nuclear, electricity, renewable energy/alternative fuels, multifuel, enduse consumption, models, and forecasts.

Questions concerning publications in the Directory should be directed to the National Energy Information Center (NEIC) at (202) 586-8800.

Comments on the Directory itself should be directed to Paula Altman of NEIC. 


\section{How to Use the EIA Publications Directory}

Availability. This directory contains abstracts and ordering information for individual issues of semiannual, annual, biennial, and triennial Energy Information Administration (EIA) periodicals, analysis reports, service reports, and model documentations. (Service reports are prepared by EIA upon special request and may be based on assumptions specified by the requestor.) Most publications are available from the National Technical Information Service (NTIS), U.S. Department of Commerce. Order numbers, indicated by a "DE" prefix, and price codes are given. If there is no order number beginning with "DE," use the DOE/EIA number when placing your order. The price codes are interpreted on page 52. The NTIS telephone number and an order form are on page 57 .

Most publications are available in paper copy. If, however, a paper copy code is not available, the publication is obtainable in microfiche only. All publications on microfiche listed as available from NTIS are available at the same price as the paper copy, except where indicated.
Periodicals produced more frequently than semiannually -- quarterlies, monthlies, and weeklies -- are listed as single titles. Individual issues are not listed, and no ordering information is given. If the periodical is current, it is available by subscription from the U.S. Government Printing Office (GPO).

Some recent individual issues are also available from GPO. Most back issues of current and discontinued periodicals are available from NTIS. For ordering information regarding these periodicals, call NTIS directly. Annual and one-time reports which are available from GPO are indicated with a GPO stock number and price. A GPO order form can be found on page 55. Publications not available from NTIS are available from NEIC. An NEIC order form is on page 59.

Abstracts. Publication abstracts are arranged by abstract number within subject categories as listed in the table of contents. The principal elements of a publication abstract entry are illustrated below.

\section{ABSTRACT}
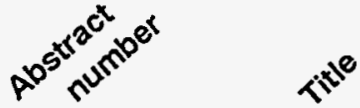

\section{Annual Energy Review 1993}

The Annual Energy Review presents historical energy data summaries (total U.S. consumption, imports, and exports) as well as complete data coverage of the principal energy commodities. Price, inventory, and resource reserve information are also provided by fuel. Additionally are presented statistics on some renewable energy sources. Most of the data series are from 1949 forward. Key international data series for major energy sources and activities are also included. Publication began with the 1982 edition.
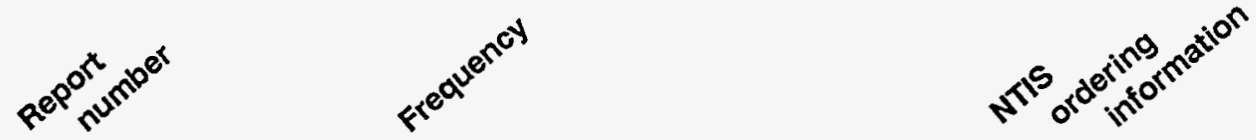

DOE/EIA-0384(93) Annual July 1994412 pp. NTIS Stock Number: DE94015828 NTIS Price Code: A18 GPO Stock Number: 061-003-00863-1 GPO Price: $\$ 25.00$

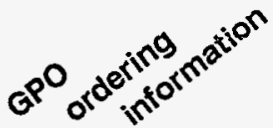


Indices. The directory has three indices: the subject index, the report number index, and the title index. Each index entry contains an abstract number which refers the reader to the publication abstract.

Subject Index. The subject index is arranged alphabetically by specific energy terminology. The numbers that follow each entry refer the reader to the related publication abstract.
Report Number Index. The report number index is arranged alpha-numerically by the DOE/EIA number. The index begins with the report number, followed by the title, date, number of pages, NTIS stock number, if available, the GPO stock number and price, if available, and the abstract number.

Title Index. The title index is arranged alphabetically and includes the same information as in the report number index.

\section{SUBJECT INDEX}

Energy Information Directory 10

Ethanol

consumption 49

production 31,33

stocks 31,33

Fergana basin

oil and gas resources 27

\section{REPORT NUMBER INDEX}

DOE/EIA-0436(94) World Nuclear Outlook 1994

Annual December 1994144 pp. NTIS Stock Number: DE95011851 NTIS Price Code: A07 GPO Stock Number: 061-003-00883-6 GPO Price: $\$ 9.0038$

\section{TITLE INDEX}

Emissions of Greenhouse Gases in the United States 1987-1992

DOE/EIA-0573 Annual October 1994144 pp. NTIS Stock Number: DE94008247 NTIS Price

Code: A07 GPO Stock Number: 061-003-00878-0 GPO Price: $\$ 9.0052$ 


\section{Contents}

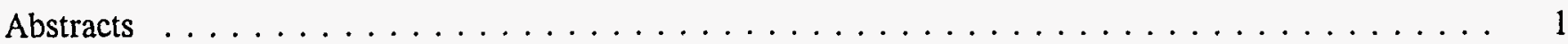

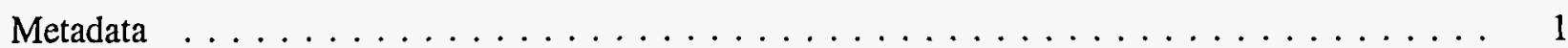

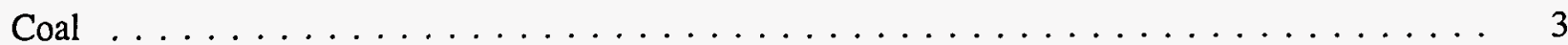

Oil and $\mathrm{Gas} \ldots \ldots \ldots \ldots \ldots \ldots \ldots \ldots \ldots \ldots \ldots \ldots \ldots$

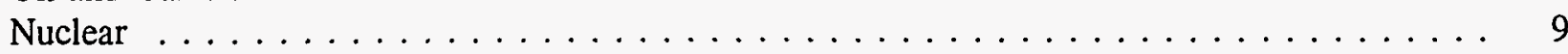

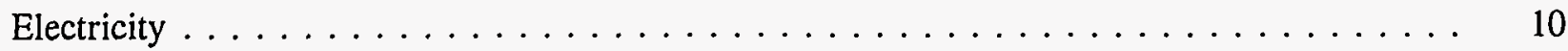

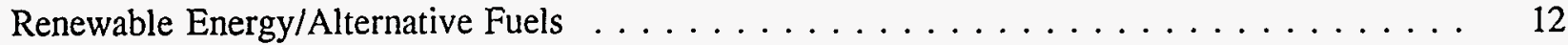

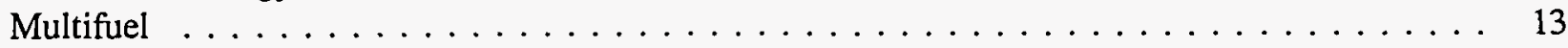

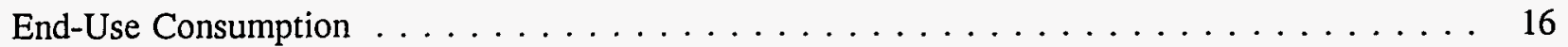

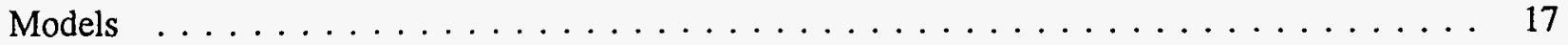

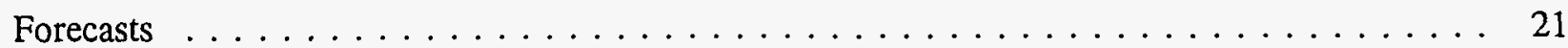

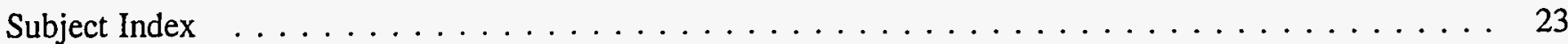

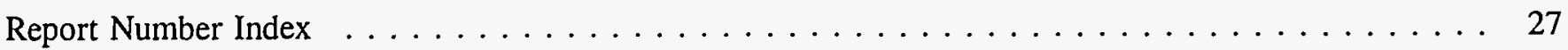

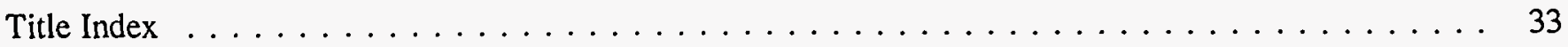

Energy Information Administration's Products and Services . . . . . . . . . . . . . 41

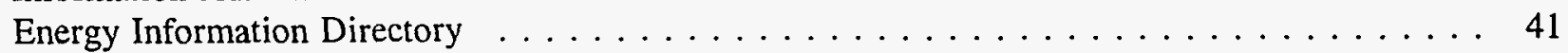

ElA New Releases $\ldots \ldots \ldots \ldots \ldots \ldots \ldots \ldots \ldots \ldots \ldots \ldots \ldots$

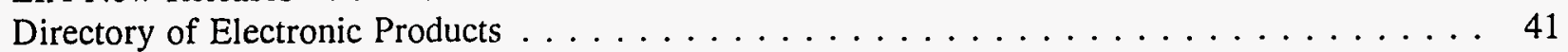

Directory of Energy Data Collection Forms . . . . . . . . . . . . . . . . 41

Directory of Energy Information Administration Models $\ldots \ldots \ldots \ldots \ldots \ldots \ldots$

Energy Information Sheets $\ldots \ldots \ldots \ldots \ldots \ldots \ldots \ldots \ldots$

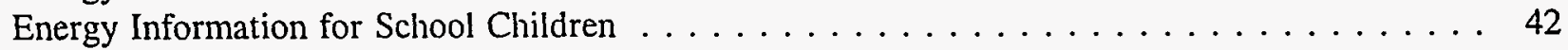

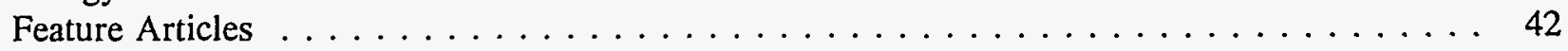

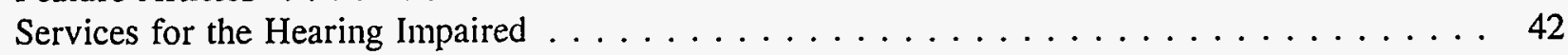

Electronic Publishing System (EPUB) $\ldots \ldots \ldots \ldots \ldots \ldots \ldots \ldots \ldots \ldots \ldots$

Comprehensive Oil and Gas Information Source $\ldots \ldots \ldots \ldots \ldots \ldots$

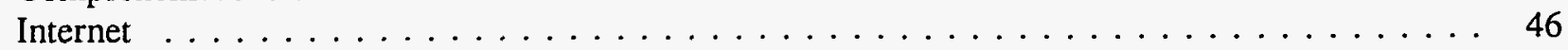

How to Order from the U.S. Government Printing Office $\ldots \ldots \ldots \ldots \ldots \ldots \ldots \ldots \ldots \ldots$

How to Order $\ldots \ldots \ldots \ldots \ldots \ldots \ldots \ldots \ldots \ldots \ldots \ldots \ldots$

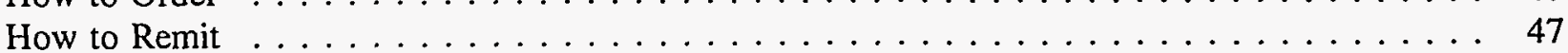

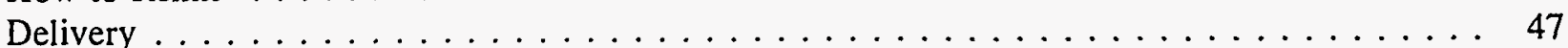

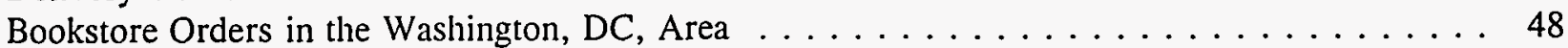

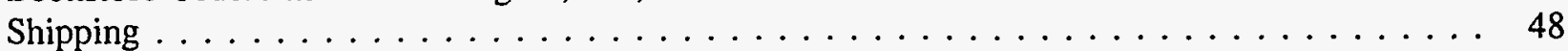

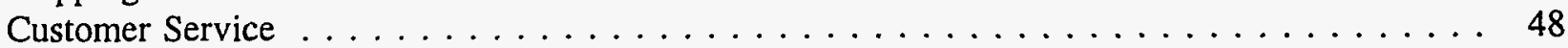

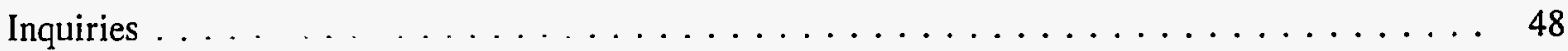

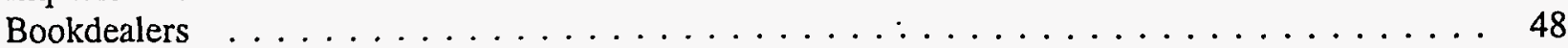

Orders for 100 or More Copies $\ldots \ldots \ldots \ldots \ldots \ldots \ldots \ldots \ldots \ldots$

Deposit Accounts . . . . . . . . . . . . . . . . . . . . . 49

International Orders $\ldots \ldots \ldots \ldots \ldots \ldots \ldots \ldots \ldots \ldots \ldots$

Government Printing Office Priority Announcement Service . . . . . . . . . . . . . . . 49

U.S. Government Depository Libraries . . . . . . . . . . . . . . . . . . . . . . . . . . . . 49 
How to Order from the National Technical Information Service . . . . . . . . . . . . . . . . 49

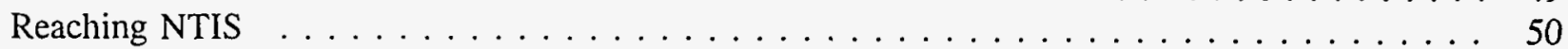

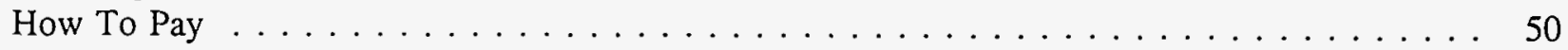

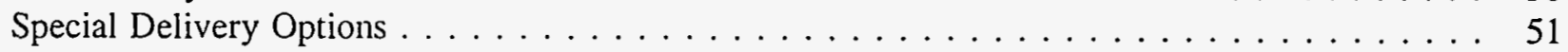

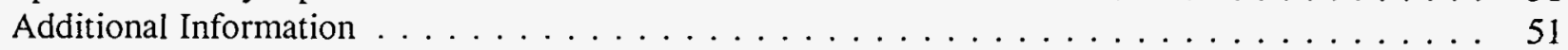

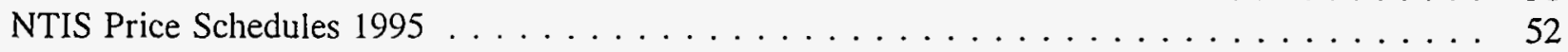

How to Order from the National Energy Information Center $\ldots \ldots \ldots \ldots \ldots \ldots$

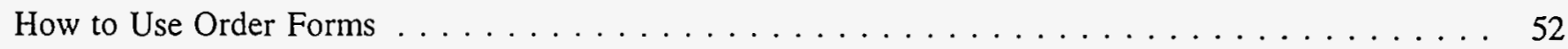

\section{Illustrations}

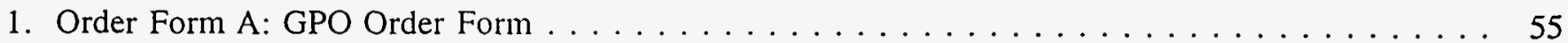

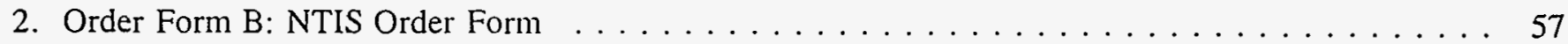

3. Order Form $\mathrm{C}$ : NEIC Order Form $\ldots \ldots \ldots \ldots \ldots \ldots \ldots \ldots \ldots \ldots$ 


\section{Abstracts}

\section{Metadata}

\section{Annual Report to Congress 1993}

Annual Report to Congress discusses accomplishments of EIA and describes the functions and responsibilities of EIA. Active models and data collection surveys are described in the appendices along with a listing of publications and periodicals published during the year. Publication began with the 1977 edition.

DOE/EIA-0173(93) Annual March 1994100 pp. NTIS Stock Number: DE94009788 NTIS Price Code: A05

\section{Directory of Energy Data Collection Forms}

This directory contains abstracts of forms used by EIA to collect energy data. Each entry contains an abstract of the form, the energy source(s) and function(s) covered by the form, identification of group(s) responding to the form, report requirements, the legislative mandate under which the data in these forms were collected and the frequency with which they were collected. The names and numbers of previous publications, of current publications resulting from the forms, and of parent reporting systems are also indicated. Detailed appendices are included, and Appendix E lists Collection Authorities, i.e., Public Laws and Code of Federal Regulations citations. Publication began November 1980.

DOE/EIA-0249(94) Annual December 199476 pp. NTIS Stock Number: DE95004329 NTIS Price Code: A05

\section{Directory of Energy Information} Administration Models 1994

Abstracts of EIA models are presented. The main body is an alphabetical listing of all active models. Brief statements regarding each model's title, acronym, purpose, and status are given, followed by more detailed information on characteristics, cases, and requirements. Sources for additional information are identified. Publication began with the 1985 edition.

DOE/EIA-0293(94) Annual July 1994100 pp. NTIS Stock Number: DE94014881 NTIS Price Code: A05

\section{EIA Directory of Electronic Products}

The EIA Directory of Electronic Products lists EIA machine-readable data files and computer models. The data files and models are made available to the public on magnetic tapes. In addition, selected data files/models are available on diskette for IBMcompatible personal computers. Selected data files and publications of EIA are accessible on-line and via CD-ROM technology. EIA and the U.S. Department of Commerce offer on-line, electronic bulletin board access to EIA files, and the Department of Commerce also issues selected EIA publications on CD-ROM. For each product listed in this directory, a detailed abstract is provided which describes the data published.

\section{DOE/EIA-0569 Quarterly Available: NEIC}

\section{EIA Guidelines for Statistical Graphs}

Guidelines to aid in resolving problems common to the presentation of data in statistical graphs are presented. Types of graphs covered are simple line graphs, cumulative line graphs, bar/pie charts, histograms, statistical maps, scatter diagrams, and 
graphs for time series. Design criteria, examples, and appropriate use for each are discussed. An appendix, bibliography, and glossary are provided.

DOE/EIA-0465(94) Irregular August 1994108 pp. Available: NEIC

\section{EIA New Releases}

The latest available EIA publications and upcoming reports are listed and described in this bimonthly publication. Availability and ordering information are provided. News about EIA and other items of interest to users of EIA publications are also included. Publication began October 1979.

\section{DOE/EIA-0204 Bimonthly Available: NEIC}

\section{EIA Publications Directory 1993}

This directory contains abstracts and ordering information for EIA publications released in the above time period. The abstracts are arranged by broad subject category such as coal, petroleum, natural gas, and electric power. A comprehensive subject index, a title index, and a report number index are included. Each entry gives the title, report number, publication frequency, date, number of pages, and ordering information. Publication began with the 1979 edition.

DOE/EIA-0149(93) Annual July 199464 pp. NTIS Stock Number: DE940I5840 NTIS Price Code: A04

\section{EIA Publications Style Manual}

This is the fourth edition of the EIA Publications Style Manual. It is intended to be a guide for EIA staff involved in the production of agency publications. The manual aids authors in creating and formatting uniform publications and reflects the changes that have taken place to streamline methods of producing publications. The first edition, in 1979, was written for writers and typists who struggled with producing reports on manual typewriters; this edition reflects the increased use of automation in preparing most agency reports for publication. It should be noted that this manual is an interim version. EIA uses two types of auto- mated publishing systems to produce most publications. EIA has had a fully automated mainframe computer photocomposition publishing system, which incorporates many of the style features discussed in this manual. The agency style is flexible enough to also accommodate the growing production by personal computer-based composition systems. The need for graphics artists to produce illustrations for reports has been significantly reduced. The basic style has changed very little and continues to be based on the U.S. Government Printing Office Style Manual.

DOE/EIA-0415(94) Annual July 199492 pp. Available: NEIC

\section{Energy Education Resources}

A compilation of sources of free or low-cost energy-related educational materials geared for primary school and secondary school students and educators. It contains names, addresses, and telephone numbers of the publishers and a brief description of materials and services available.

DOE/EIA-0546(93) Annual February 199448 pp. NTIS Stock Number: DE95009455 NTIS Price Code: A03

\section{Energy Information Directory}

Various energy information offices within the Department of Energy (DOE), other Federal agencies, State agencies, and trade associations are listed. Entries are arranged in sections presenting the names of the office, the address, phone number, principal contact person, and a description of primary activities. A comprehensive subject index is also provided. Publication began in 1979 under the title Energy Information Referral Directory.

DOE/EIA-0205(94) Annual March 1994140 pp. NTIS Stock Number: DE94009431 NTIS Price Code: A07

\section{PEDRO User Guide}

The PC Electronic Data Reporting Option (PEDRO) User Guide has been designed by EIA to introduce the new user to the PEDRO system and its features. 
PEDRO is an electronic data collection product that simplifies filing and transmission of energy survey data. The Guide is divided into four chapters and appendices: Chapter 1 explains PEDRO to the new user and how one may participate in the program; Chapter 2 provides general instruction for using PEDRO and upgrades to the system; Chapter 3 provides installation procedures; Chapter 4 explains in detail how to use PEDRO and how to process and transmit survey data. The appendices contain solutions to error messages and problems, examples of PEDRO's control files, and survey-specific information.

DOE/EIA-0528(94) One-time February 1994 136 pp. NTIS Stock Number: DE95009454 NTIS Price Code: A07

\section{Reserves Information Gathering System} User's Guide

This report provides detailed instructions on how to use the Reserves Information Gathering System (RIGS) which allows survey respondents a timely alternative for submission of Form EIA-23, "Annual Survey of Domestic Oil and Gas Reserves." System requirements are outlined along with the basic data entry steps. The Guide also includes help facilities information and appendices that describe the system's structure and answers to commonly asked questions.

DOE/EIA-0530 One-time January 199480 pp. NTIS Stock Number: DE95009453 NTIS Price Code: A05

\section{Coal}

\section{Coal Industry Annual 1993}

The Coal Industry Annual 1993 replaces the publication Coal Production (DOE/EIA-0118). This report is the 18th annual report on coal production published by EIA. Additional tables and expanded versions of tables previously presented in Coal Production are provided including production, number of mines, productivity, employment, productive capacity, and recoverable reserves. Data are also provided on coal consumption, distribution, stocks, prices, quality, and emissions for a wide audience. Trends for 5 and 10 years are presented for major data categories. Displayed for the first time are lists of major coal producers, distributors, consumers, and union related data. In addition, an appendix contains a compilation of coal statistics for the major coal-producing States. The Demonstrated Reserve Base (DRB) data that were presented in Coal Production are not published in this report as these data are now reported in U.S. Coal Reserves: An Update by Heat and Sulfur Content (DOE/EIA0529). However, this report contains the recoverable portion of the DRB.

DOE/EIA-0584(93) Annual December 1994286 pp. NTIS Stock Number: DE95004326 NTIS Price Code: A13 GPO Stock Number: 061-003-00882-8 GPO Price: $\$ 22.00$

\section{Quarterly Coal Report}

This report provides information about U.S. coal production, distribution, exports, imports, receipts, prices, consumption, and stocks. Coke production, consumption, distribution, imports, and exports data are also provided. Beginning with the first quarter (1992), Quarterly Coal Report includes distribution data formerly published in Coal Distribution and an expansion of the Receipts Section, which provides additional data on the quality of coal receipts at electric utility plants. Each issue presents detailed data for the most recent quarter and aggregated quarterly historical data. Appendix A displays, from 1980 forward, detailed quarterly historical data of imported coal received at the electric utility plants. Appendix B gives selected quarterly tables converted to metric tons. Explanatory notes are presented in Appendix C. A glossary is also included. Publication began with 1982 data.

DOE/EIA-0121 Quarterly GPO Subscription List ID: QCR GPO Subscription Price: $\$ 26.00$

\section{State Coal Profiles}

State Coal Profiles provides basic information about the deposits, production, and use of coal in each of the 27 coal-producing States in 1992. Each coalproducing State is profiled with a description of its 
coal deposits and a discussion of the development of its coal industry. Estimates of coal reserves are categorized by mining method and sulfur content. Trends, patterns, and other information concerning production, number of mines, miners, productivity, mine price of coal, disposition and consumption of coal are detailed in statistical tables for selected years. In addition, coal's contribution to the State's estimated total energy consumption is given. A U.S. summary of all data is provided for comparing individual States with the Nation as a whole. Sources of information are given at the end of the tables.

DOE/EIA-0576 One-time February 1994148 pp. NTIS Stock Number: DE94007086 NTIS Price Code: A07 GPO Stock Number: 061-003-00844-5 GPO Price: $\$ 10.00$

\section{Weekly Coal Production}

National, regional, and State-level data on the production of bituminous coal and lignite and on the production of Pennsylvania anthracite are reported for each of the two most recent weeks and a corresponding week in the previous year. Also shown is current year-to-date production, year-todate production for a corresponding period in the previous year, production for the most recent 52week period, and production for a corresponding period in the previous year. Also reported is the number of railroad cars loaded in each time period. Highlights are presented in the Summary. Publication began May 1980.

DOE/EIA-0218 Weekly GPO Subscription List ID: WCPBA GPO Subscription Price: $\$ 85.00$

\section{Oil and Gas}

\section{Cost and Indices for Domestic Oil and} Gas Field Equipment and Production Operations 1990-1993

This is EIA's 12th report in the series of oil and gas field equipment and operating costs and indices for the domestic oil and gas producing industry. The purpose of this series is to provide a continuing means of gauging the changes in the oil and gas producing industry's costs of equipment and production operations. The costs of all equipment and services were those in effect during June of each year. This report presents estimated costs for 1990 , 1991, 1992, and 1993. The information is given for several depth categories, both offshore and onshore, in oil-producing regions of the United States. Appendices give detailed statistics. A glossary is included.

DOE/EIA-TR-0568 One-time July 1994124 pp. NTIS Stock Number: DE94015132 NTIS Price Code: A06 GPO Stock Number: 061-003-00862-3 GPO Price: $\$ 7.50$

18 Energy Information Administration's Assessment of Reformulated Gasoline, The; Volume 1

DOE/EIA-SR/OOG/94-02/1 Service Report

October 1994106 pp. NTIS Stock Number: DE95009451 NTIS Price Code: A06 GPO Stock Number: 061-003-00874-7 GPO Price: $\$ 6.50$

\section{Energy Information Administration's} Assessment of Reformulated Gasoline, The; Volume 2

DOE/EIA-SR/OOG/94-02/2 Service Report

October 1994166 pp. NTIS Stock Number: DE95009452 NTIS Price Code: A08 GPO Stock Number: 061-003-00875-5 GPO Price: $\$ 11.00$

\section{Energy Information Administration's} Assessment of Reformulated Gasoline, The: An Update

DOE/EIA-SR/OOG/94-03 Service Report

December 199444 pp. NTIS Stock Number: DE95004836 NTIS Price Code: A03

A benchmark for industry and government in tracking market conditions of reformulated gasoline (RFG). This study is a two-part report containing two volumes and an update. Part I, containing Volumes 1 and 2, was published as EIA's Assessment of Reformulated Gasoline and is largely 
based upon planning estimates and forecasts developed in advance of the actual production, importation, and stocking of RFG. Volume 1 contains EIA's findings and analyses on reformulated gasoline as it affects the petroleum industry. Volume 2 contains 10 appendices that include survey results, survey forms, and historical summary data. Part II, An Update, concludes and updates EIA's initial report as the actual RFG situation became more apparent. A glossary and a list of acronyms and abbreviations are printed in Volumes 1 and 2.

\section{Fuel Oil and Kerosene Sales 1993}

This report presents statistics on sales of fuel oil and kerosene. The majority of the tables in this report show sales data for the current reporting year while other tables present a historical time series with data shown for the most recent 5-year period. End-use data in this report are given for the total United States as well as by State, Petroleum Administration for Defense (PAD) district, residential, commercial, and industrial sectors, oil companies, farms, electric utilities, railroads, vessel bunkering, military, on-highway, and off highway. Prior to the publication of this report, the statistics appeared in the Petroleum Marketing Annual for reference year 1988 and the Petroleum Marketing Monthly for reference years 1984 through 1987. This report is the 10th annual presentation of the results of the ongoing "Annual Fuel Oil and Kerosene Sales Report" (Form EIA-821) survey.

DOE/EIA-0535(93) Annual October 199460 pp. NTIS Stock Number: DE95001361 NTIS Price Code: A04 GPO Stock Number: 061-003-00877-1 GPO Price: $\$ 4.00$

\section{International Petroleum Statistics \\ Report}

This report presents data on international oil production, consumption, imports, exports, and stocks. Also included is an oil market chronology of significant recent events in world petroleum markets. Section 1 contains time series data on world oil production and oil consumption and stocks in the Organization for Economic Cooperation and Development (OECD) and its member nations. This section contains annual data beginning in 1985 and monthly data for the most recent 2 years. Section 2 presents an oil supply/consumption balance for the market economies as well as China and the former Soviet Union. This balance is presented in quarterly intervals for the most recent 2 years, and annual averages for the most recent 5 years. Section 3 presents data on oil imports by OECD countries from selected members of the Organization of Petroleum Exporting Countries (OPEC). This section contains annual data for the last calendar year, quarterly data for the last 2 quarters, and monthly data for the most recent 12 months. Section 4 contains historical oil statistics similar to those found in Sections 1 through 3. Data in this section are presented annually back to 1983 , and often back to 1970 , on a country-by-country basis. Publication of this report began in 1989.

DOE/EIA-0520 Monthly GPO Subscription List ID: IPSR GPO Subscription Price: $\$ 43.00$

\section{Natural Gas 1994: Issues and Trends}

This report provides an overview of the natural gas industry in 1993 and early 1994, focusing on the overall ability to deliver gas under the new regulatory mandates of the Federal Energy Regulatory Commission's Order 636. The report also looks at restructuring under Order 636. In addition the report highlights a range of other issues affecting the industry such as adjustments in natural gas contracting, increased use of storage, the financial performance of the industry, and the continuing impacts of regulatory and legislative changes.

DOE/EIA-0560(94) Annual July 1994176 pp. NTIS Stock Number: DE94017190 NTIS Price Code: A09 GPO Stock Number: 061-003-00860-7 GPO Price: $\$ 11.00$

\section{Natural Gas Annual 1992 Supplement: Company Profiles}

The purpose of this report is to show the movement of natural gas through the various States served by the 45 large companies profiled. The companies in the report are interstate pipeline companies or large local distribution companies or combination companies with both pipeline and distribution 
operations. The company profiles are presented with pipeline system and service area maps. Company supply and disposition data are presented for the States of operation as reported on the Form EIA176.

DOE/EIA-0131(92)/S Annual February 1994 216 pp. NTIS Stock Number: DE94006727 NTIS Price Code: A10 GPO Stock Number: 061-003-00843-7 GPO Price: $\$ 14.00$

\section{Natural Gas Annual 1993}

The Natural Gas Annual provides information on the supply, disposition, and price of natural gas. The 1993 data are presented in a sequence that follows natural gas from its production to its end use. Tables summarizing natural gas supply and disposition from 1989 to 1993 are given for each Census division and each State. Annual historical data are shown at the national level.

DOE/EIA-0131(93) Annual October 1994264 pp. NTIS Stock Number: DE95002470 NTIS Price Code: A12 GPO Stock Number: 061-003-00879-8 GPO Price: $\$ 16.00$

\section{Natural Gas Monthlv}

Current data on natural and supplemental gas production, supply, consumption, disposition, interstate pipeline activities, storage, imports, exports, and prices in the United States are presented. Production and storage data are given by State; consumption and price data are given by State and sector; company-specific data on interstate pipelines are also presented. Explanatory notes, a discussion of data sources, and a glossary are included. Feature articles on current topics are published periodically, and a report on imports/exports is published annually. Publication began November 1982.

DOE/EIA-0130 Monthly GPO Subscription List ID: NSG GPO Subscription Price: $\$ 78.00$

\section{Natural Gas Productive Capacity for} the Lower 48 States 1980 through 1995

The purpose of this study is to prepare a historical analysis of the monthly productive capacity of natural gas at the wellhead from 1980 through 1992 and project this capacity from 1993 through 1995 in the lower 48 States. The impact of drilling, oil and gas price assumptions, and demand on gas productive capacity are examined. Both gas-well gas and oil-well gas are included in the study. Oil-well gas productive capacity was estimated separately, then was combined with the gas-well gas productive capacity.

DOE/EIA-0542(95) Annual July 1994124 pp. NTIS Stock Number: DE94016592 NTIS Price Code: A06

\section{Oil and Gas Field Code Master List 1994}

The Oil and Gas Field Code Master List provides standardized field name spellings and unique six-digit codes for all identified oil and/or gas fields in the United States. For each field, the master list displays the field code, the field name, State postal abbreviation and State subdivision code, county code, county name, field discovery year, and field type. Also provided is a list of "alias" or alternate field names. The master list field name spellings and codes are to be used by respondents to Department of Energy forms. Publication began with the 1992 edition.

DOE/EIA-0370(94) Annual December 1994454 pp. NTIS Stock Number: DE95004719 NTIS Price Code: A20 GPO Stock Number: 061-003-00890-9 GPO Price: $\$ 27.00$

\section{Oil and Gas Resources of the Fergana} Basin (Uzbekistan, Tadzhikistan, and Kyrgyzstan)

This technical report is part of EIA's Foreign Energy Supply Assessment Program (FESAP). While past FESAP analyses covered most of the major oil and gas provinces of the world, this one for the Fergana basin is an EIA first for republics of the former Soviet Union.

DOE/EIA-TR/0575 One-time December 1994 160 pp. NTIS Stock Number: DE95004722 NTIS Price Code: A08 GPO Stock Number: 061-003-00886-1 GPO Price: $\$ 11.00$ 


\section{Petroleum Marketing Annual 1993}

Petroleum product marketing data are reported by State and Petroleum Administration for Defense (PAD) district. National-level statistics on crude oil and petroleum products are also given. Five sections display summary statistics, crude oil prices, sales prices of products, sales volumes, and first sales of products for consumption. Sales price and volume data cover motor gasoline, distillate fuel oil, residual fuel oil, aviation fuels, kerosene, and propane. Marketing data are given by type of seller (major refiner, other refiner/gas plant operator, and reseller) and by type of sale (sales to end users and sales for resale). Data on crude oil present domestic first purchase price by State and free on board/landed cost of imported crude oil by country of origin, gravity, and crude stream. These data are compiled from six surveys. An appendix presents historical price data by State for the years 1983 to 1993. Explanatory notes and a glossary are included. Publication began with 1985 edition.

DOE/EIA-0487(93) Annual December 1994428 pp. NTIS Stock Number: DE95005364 NTIS Price Code: A19 GPO Stock Number: 061-003-00892-5 GPO Price: $\$ 31.00$

\section{Petroleum Marketing Monthly}

Petroleum product marketing data are reported for the United States, Petroleum Administration for Defense (PAD) districts, and selected States, depending on the petroleum product, for the current month, the previous month, and the corresponding month of the previous year. Some data are also summarized for each year from 1978 forward and for each month from the previous 2 years through the current month. Shown for 16 individual petroleum products are sales prices, sales volumes, and first sales for consumption. Data are given by type of seller (major refiner, other refiner/gas plant operator, and reseller) and by type of sale (sales to end-users and sales for resale). Crude oil price tables present data from 1978 through the current month on refiner acquisition cost; first purchase price by State; and free on board/landed cost of purchases for U.S. importation from selected countries, by API gravity, and for selected crude streams. Feature articles on current topics appear periodically. Standard errors and survey response percentages are also presented. Explanatory notes, a glossary, and a product guide to tables are also included. Publication began May 1983.

DOE/EIA-0380 Monthly GPO Subscription List ID: PMM GPO Subscription Price: $\$ 83.00$

\section{Petroleum Supply Annual 1993, Volume 1 \\ DOE/EIA-0340(93)/1 Annual June 1994200 pp. NTIS Stock Number: DE94013720 NTIS Price Code: A09}

\section{Petroleum Supply Annual 1993, Volume 2 \\ DOE/EIA-0340(93)/2 Annual June 1994608 pp. NTIS Stock Number: DE94013718 NTIS Price Code: A99 GPO Stock Number: 061-003-00856-9 GPO Price: $\$ 37.00$}

The Petroleum Supply Annual consists of two volumes. Volume 1 contains annual supply, disposition, and stock data beginning in 1973. Monthly data are given for the most recent 3 years. Supply and disposition are reported for crude oil, natural gas liquids and liquefied refinery gases (LRG's), individual finished petroleum products and other liquids. The movements of crude oil and petroleum products between Petroleum Administration for Defense (PAD) districts are detailed as well as imports and exports of crude oil and petroleum products by country, and the production of heavy oils by sulfur content. Volume 2 contains supply and disposition data for each month of the current year. Supply and disposition are reported for crude oil, natural gas plant liquids/LRG's, other liquids, and individual finished petroleum products. Movements of crude oil and petroleum products between PAD districts by pipeline, tanker and barge are detailed, as well as imports and exports of crude oil and petroleum products by country, and the imports of residual fuel oil by sulfur content. Publication began with the 1981 edition. 


\section{Petroleum Supply Monthly}

Contains summary data on the supply and disposition of crude oil and petroleum products in the United States and major U.S. geographic regions. The data series describe monthly production, imports and exports, inter-Petroleum Administration for Defense (PAD) district movements, and inventories by the primary suppliers of petroleum products in the United States (50 States and the District of Columbia). The reporting universe includes petroleum refiners, motor gasoline blenders, operators of natural gas processing plants and fractionators, inter-PAD district transporters, importers, and major inventory holders of petroleum products and crude oil. Data presented are divided into two sections: (1) "Summary Statistics" and (2) "Detailed Statistics." The tables and figures in the "Summary Statistics" section present a time series of selected petroleum data on a U.S. level. Tables in the "Detailed Statistics" section present statistics for the most current month available as well as year-to-date. Also presented are the results of Form EIA-819, "Monthly Oxygenate Telephone Report." Publication began March 1982.

DOE/EIA-0109 Monthly GPO Subscription List ID: PETS GPO Subscription Price: $\$ 80.00$

\section{U.S. Crude Oil, Natural Gas, and Natural Gas Liquids Reserves 1993 Annual Report}

Proved reserves of crude oil, natural gas, and natural gas liquids in the United States are reported by State with U.S. totals. A national summary is given, along with a discussion of notable areas of industry activity. The appendices contain information on operator data by size class, the top 100 oil and gas fields (for 1992), reserves data converted into metric units, historical reserves statistics, a summary of data collection operations, a discussion of statistical issues, a discussion of reserve estimation methodologies, maps of selected State subdivisions, and examples of the survey forms used. Publication began with the 1977 edition.

DOE/EIA-0216(93) Annual October 1994168 pp. NTIS Stock Number: DE95002536 NTIS Price Code: A08 GPO Stock Number: 061-003-00876-3 GPO Price: $\$ 12.00$

\section{Weekly Petroleum Status Report}

Information on the petroleum supply situation in the United States is presented for the current week and most recent month. Some monthly data go back 2 or 3 years. Shown are the U.S. petroleum balance sheet, refinery activity, stocks, imports, products supplied, and prices. Data include: refinery inputs, utilization, and production; stocks of crude oil and major products (gasoline, distillate fuel oil, residual fuel oil, etc.) by Petroleum Administration for Defense district; refiner acquisition cost of crude oil; retail selling prices for motor gasoline and residential heating oil; world crude oil prices; and spot market product prices. Strategic Petroleum Reserve data are shown when appropriate. Appendix A presents explanatory notes, and Appendix B presents the results of Form EIA-819, "Monthly Oxygenate Telephone Report." A glossary is also provided. Publication began April 1979.

DOE/EIA-0208 Weekly GPO Subscription List ID: EWPSR GPO Subscription Price: $\$ 65.00$

\section{Winter Fuels Report}

This weekly report contains monthly and weekly propane and fuel oil data, natural gas supply and disposition data, and selected price information. The report presents distillate fuel oil net production, imports, and stocks for all Petroleum Administration for Defense (PAD) districts, and product supplied on a U.S. level. It provides propane and propylene net production, imports, and stocks on a U.S. level and for PAD Districts I, II, and III. Natural gas supply and disposition and underground storage for the United States are provided, as well as consumption for all PAD districts. For selected States, residential and wholesale pricing data for propane and heating oil are listed, in addition to U.S. crude oil, No. 2 distillate, and propane prices for selected cities. Finally, the report includes a brief weather summary with U.S. total heating degree-days by city, appendices showing PAD district descriptions and maps, explanatory notes, and a glossary. This report will be published only during the heating season, terminating the first week in April. Publication began in October 1990.

DOE/EIA-0538 Weekly, October - April 


\section{Nuclear}

\section{Spent Nuclear Fuel Discharges from} U.S. Reactors 1992

Spent Nuclear Fuel Discharges from U.S. Reactors 1992 provides current statistical data on fuel assemblies irradiated at commercial nuclear reactors operating in the United States. This year's report provides data on the current inventories and storage capacities at these reactors. Data are collected on Form RW-859, "Nuclear Fuel Data" survey, and provide a comprehensive statistical characterization of the industry's activities for the survey year and include some information about industry plans and commitments for the future. Detailed statistics on these data are presented in four chapters that highlight 1992 spent fuel discharges, storage capacities and inventories, canister and nonfuel component data, and assemble characteristics. Five appendices, a glossary, and bibliography are also included.

DOE/EIA-SR/CNEAF/94-01 Service Report May 1994254 pp. NTIS Stock Number: DE94011195 NTIS Price Code: A12

\section{Uranium Industry Annual 1993}

Information on the U.S. uranium industry is presented. Uranium raw material activities described include exploration, resources, mine production, milling operations, and employment. Uranium marketing activities discussed include: utility purchases, uranium prices, domestic procurement, foreign purchases, enrichment, inventories, market requirements, and availability. This information is collected on Form EIA-858, "Uranium Industry Annual Survey." This report contains data previously reported in Survey of United States Uranium Marketing Activity (DOE/EIA-0403) and Survey of U.S. Uranium Exploration Activity (DOE/ElA-0402). Appendices describe the survey methodology, provide technical notes, list respondents to the survey, and present the survey form. A glossary is included. Publication began with the 1984 edition.

DOE/EIA-0478(93) Annual September 1994148 pp. NTIS Stock Number: DE94018625 NTIS Price Code: A07 GPO Stock Number: 061-003-00872-1 GPO Price: $\$ 10.00$

\section{Uranium Purchases Report 1993}

This report provides data on the amount of uranium purchased by electric utilities from domestic sources and from foreign sources by material type and country of origin. It also includes data on the amount of enrichment feed deliveries to U.S. and to non-U.S. enrichers by country of origin of the uranium. It contains a list of sellers of uranium to U.S. utilities under new domestic and new imported uranium purchase contracts for 1992. This report is the second in a series of annual publications by EIA required by the Energy Policy Act of 1992.

DOE/EIA-0570(93) Annual August $199412 \mathrm{pp}$. NTIS Stock Number: DE94018015 NTIS Price Code: A03 GPO Stock Number: 061-003-00867-4 GPO Price: $\$ 1.50$

\section{World Nuclear Outlook 1994}

This report presents the current status and projections through 2010 of nuclear capacity, generation, and fuel cycle requirements for all countries in the world using nuclear power to generate electricity for commercial use. It also contains information and forecasts of developments in the uranium market. In addition, it presents projections of U.S. nuclear capacity, generation, and spent fuel discharges through 2040. This report was formerly published as World Nuclear Capacity and Fuel Cycle Requirements, which began publication with the 1983 edition.

DOE/EIA-0436(94) Annual December 1994144 pp. NTIS Stock Number: DE95011851 NTIS Price Code: A07 GPO Stock Number: 061-003-00883-6 GPO Price: $\$ 9.00$ 


\section{Electricity}

39 Cost and Quality of Fuels for Electric Utility Plants 1993

Annual information on the cost and quality of tossil fuel receipts at electric utility plants is presented, with some data presented in a historical series. Data on receipts, cost, and quality are reported by individual plant and utility company, and data on receipts and cost are also aggregated by State and Census division. Through 1983, data are reported for plants with a capacity of 25 megawatts or greater. Since 1984, the data are for plants with 50 megawatts or greater capacity. Publication began with the 1978 edition.

DOE/EIA-0191(93) Annual July 1994188 pp. NTIS Stock Number: DE94015595 NTIS Price Code: A09 GPO Stock Number: 061-003-00864-0 GPO Price: $\$ 13.00$

\section{Electric Power Annual 1993}

DOE/EIA-0348(93) Annual December 1994198 pp. NTIS Stock Number: DE95004328 NTIS Price Code: A09 GPO Stock Number: 061-003-00884-4 GPO Price: $\$ 13.00$

\section{Electric Power Annual 1992}

DOE/EIA-0348(92) Annual January 1994196 pp. NTIS Stock Number: DE94005401 NTIS Price Code: A09

This publication presents a summary of electric utility statistics at the national, regional, and State levels on the following subjects: generating capability and planned capability additions; net generation; fossil-fuel consumption, receipts, and average delivered cost; sales of electricity to ultimate consumers, revenue from associated sales, and average revenue per kilowatthour sold. Composite data on the financial results of operations of selected investor-owned and publicly owned utilities are presented; summary environmental statistics on gaseous emissions and environmental equipment are included; information on electric power transactions are summarized; electric utility demand-side management statistics are presented; and data on nonutility power producers are also presented. Publication began with 1981 edition.

\section{Electric Power Monthly}

This report presents monthly summaries of electric utility statistics at the national, Census division, and State levels for net generation, fuel consumption, fuel stocks, quantity and quality of fuel, cost of fuel, electricity sales, and average retail prices of electricity. Data on net generation are also presented by North American Electric Reliability Council region. In addition, company and plant specific information on the capability of new plants is presented. Beginning with the February 1989 issue, plant level data are given for net generation, fuel consumption, fuel stocks and the quantity, cost, and quality of fuel receipts each month. Publication began June 1980 .

DOE/EIA-0226 Monthly GPO Subscription List ID: EPM GPO Subscription Price: $\$ 87.00$

\section{Electric Sales and Revenue 1992}

This report provides information on sales of electricity, associated revenue, and the average revenue per kilowatthour sold to residential, commercial, industrial, and other consumers throughout the United States. Data are presented at the national, Census division, State, and utility levels. Publication began under the title Electric Sales, Revenue, and Bills 1988 which, in addition to the sales and revenue data, contained information on typical monthly electricity bills for specified levels of demand and consumption. This information on bills had previously appeared in the publication Typical Electric Bills.

DOE/EIA-0540(92) Annual April 1994244 pp. NTIS Stock Number: DE94010428 NTIS Price Code: A11

\section{Electric Trade in the United States 1992}

This report provides data on the U.S. electric utility industry's domestic and international wholesale trade and the quantities of electricity carried by the U.S. 
transmission system. Data for purchased power, sales for resale, exchanges, and transmission for and by others (wheeling) are presented. Data are at the national, North American Electric Reliability Council region, and electric utility levels and cover all utility ownership classes. An introduction discusses current conditions and emerging issues affecting electricity trade. Appendices and a glossary are also provided. Publication began with the 1986 edition.

DOE/EIA-0531(92) Biennial September 1994384 pp. NTIS Stock Number: DE94019002 NTIS Price Code: A17

\section{Electric Utility Phase I Acid Rain Compliance Strategies for the Clean Air Act Amendments of 1990}

The purpose of this report is to provide information on strategies utilities are using to comply with Phase I of the Clean Air Act Amendments of 1990 and estimates of the costs of selected utilities for compliance. Compliance strategies are discussed including technological considerations and costs for the six main strategies: (1) fuel switching and/or blending, (2) obtaining additional allowances, (3) installing flue gas desulfurization equipment (scrubbers), (4) using previously implemented controls, (5) retiring facilities, and (6) boiler repowering. Impacts on coal demand and supply are also examined.

DOE/EIA-0582 One-time March 1994132 pp. NTIS Stock Number: DE94009536 NTIS Price Code: A07 GPO Stock Number: 061-003-00848-8 GPO Price: $\$ 9.00$

\section{Financial Impacts of Nonutility Power} Purchases on Investor-Owned Electric Utilities

The primary purpose of this report is to provide an overview of the issues surrounding the financial impacts of nonutility generation contracts (since the passage of the Public Utility Regulatory Policies Act of 1978) on investor-owned utilities. The existing concern in this area is manifest in the provisions of Section 712 of the Energy Policy Act of 1992, which required State regulatory commissions to evaluate various aspects of long-term power purchase contracts, including their impact on investor-owned utilities' cost of capital and rates charged to customers.

DOE/EIA-0580 One-time June $1994112 \mathrm{pp}$. NTIS Stock Number: DE94013416 NTIS Price Code: A06 GPO Stock Number: 061-003-00857-7 GPO Price: $\$ 7.00$

\section{Financial Statistics of Major Publicly Owned Electric Utilities 1992}

Financial data for privately owned utilities are reported for the current year with summary data given for 4 prior years. Data include balance sheets; income/retained earnings statements; statement of changes in financial position; electric utility operating revenues, sales, and customers by classes of service; electric utility operation/maintenance expenses; physical quantities; selected financial indicators; research/development/demonstration; and environmental protection expenses. Data are given for all utilities combined and for each individual utility. Data were collected on FERC Form 1, "Annual Report of Major Electric Utilities, Licensees, and Others." In 1982, EIA combined the contents of two publications containing financial statistics of investor-owned (private) and publicly owned electric utilities into a single volume, the Financial Statistics of Selected Electric Utilities. In 1989, EIA reverted to two separate publications.

DOE/EIA-0437(92)/2 Annual January 1994544 pp. NTIS Stock Number: DE94007105 NTIS Price Code: A23 GPO Stock Number: 061-003-00845-3 GPO Price: $\$ 33.00$

\section{Inventory of Power Plants in the United States 1993}

This report presents year-end statistics about electric generating units operated by electric utilities in the United States. Summary data presented include aggregate capacity statistics at the national and regional levels by prime mover and by energy source, planned capacity additions by year, planned retirements by year, and capacity additions and retirements during 1993. Detailed data include the 
name of the electric utility that operates the unit, the location of the unit, the type of unit (prime mover), the primary and alternate energy source, the installed generator nameplate capacity, the net summer capability, the net winter capability, and the initial year of operation. Also included are detailed information on units owned jointly by two or more utilities, and data about proposed changes (modifications and retirements) in existing (operable and previously retired) electric generating units. Publication began with the 1979 edition.

DOE/EIA-0095(93) Annual December 1994402 pp. NTIS Stock Number: DE95004720 NTIS Price Code: A18 GPO Stock Number: 061-003-00888-7 GPO Price: $\$ 24.00$

\section{Renewable Energy/ Alternative Fuels}

\section{Alternatives to Traditional Transportation Fuels: an Overview}

This report presents the first compilation by EIA of information on alternatives to gasoline and diesel fuel as required by Section 503 of the Energy Policy Act of 1992. Information is included on the number and type of alternative-fueled vehicles in existence, the geographic distribution of these vehicles, the amounts and types of replacement fuels consumed, and the greenhouse gas emissions likely to result from replacement fuel use.

DOE/EIA-0585/O One-time June 1994164 pp. NTIS Stock Number: DE94014979 NTIS Price Code: A08 GPO Stock Number: 061-003-00859-3 GPO Price: $\$ 12.00$

\section{Estimates of U.S. Biomass Energy Consumption 1992}

This report presents estimates of biomass and biofuel energy consumption during the reported calendar year. It provides data and information on biomass fuels such as wood, municipal and industrial waste, and biomass-derived ethanol. Information is based on government reports and data surveys, industry data, and derived estimates. Statistical presentation is organized according to fuel type and end-use and provides regional and national totals. This publication was preceded by Estimates of Biofuels Consumption in the United States During 1987, Estimates of U.S. Biofuels Energy Consumption 1981-1984, Estimates of Wood Energy Consumption 1980-1983, and Estimates of Wood Energy Consumption 1949-1981.

DOE/EIA-0548(92) Annual May 199456 pp. NTIS Stock Number: DE94011458 NTIS Price Code: A04 GPO Stock Number: 061-003-00852-6 GPO Price: $\$ 3.75$

\section{Solar Collector Manufacturing Activity 1993}

This report presents a statistical profile of the solar thermal collector and photovoltaic cell/modules manufacturing industry. The results of a continuing survey of private firms which manufacture and sell solar collectors in the United States are reported. Discussed in detail are producer shipments, import and export activity, production breakdown by type of collector, values of shipment, prices, end uses and market sector, and the number of applications for solar collectors. Six classes of solar collectors are surveyed: low temperature, medium temperature, high temperature, crystalline silicon, thin-film silicon, and concentrator silicon. Data are tabulated by type of collector, by end use and by market sector (residential, commercial, industrial, utility, etc.). Some comparative data for previous years are shown. The report includes the survey methodology, a sample of the survey forms used (CE-63A, CE-63B), an appendix listing the solar collector manufacturer respondents, photovoltaic module/cell respondents, U.S. customary unit of measurements, and solar collector installed capacity and energy production. Publication began as a semi-annual with data for January to June 1977.

DOE/EIA-0174(93) Annual August $199484 \mathrm{pp}$. NTIS Stock Number: DE94017340 NTIS Price Code: A05 GPO Stock Number: 061-003-00870-4 GPO Price: $\$ 5.50$ 


\section{Multifuel}

\section{Annual Energy Review 1993}

The Annual Energy Review presents historical energy data summaries (total U.S. consumption, imports, and exports) as well as complete data coverage of the principal energy commodities. Price, inventory, and resource reserve information are also provided by fuel. Statistics on some renewable energy sources are also presented. Most of the data series are from 1949 forward. Key international data series for major energy sources and activities are also included. Publication began with the 1982 edition.

DOE/EIA-0384(93) Annual July 1994412 pp. NTIS Stock Number: DE94015828 NTIS Price Code: A18 GPO Stock Number: 061-003-00863-1 GPO Price: $\$ 25.00$

\section{Emissions of Greenhouse Gases in the United States 1987-1992}

Mandated by Congress through Section 1605(a) of the Energy Policy Act of 1992 (Title XVI), this report is the first annual update of Emissions of Greenhouse Gases 1985-1990, published in September 1993. Estimates in this report are for the years 1987-1992, and show U.S. emissions of the principal greenhouse gases--carbon dioxide, methane, nitrous oxide, chlorofluorocarbons, carbon monoxide, nitrogen oxides, and nonmethane volatile organic compounds. Appendices include carbon coefficients used in the report, emission sources excluded, and common conversion factors. A listing of references and a glossary are also included.

DOE/EIA-0573 Annual October 1994144 pp. NTIS Stock Number: DE94008247 NTIS Price Code: A07 GPO Stock Number: 061-003-00878-0 GPO Price: $\$ 9.00$

\section{End-Use Taxes: Current EIA Practices}

This publication reports the findings of the Office of Statistical Standards (OSS) review of the State Energy Price and Expenditure Data System (SEPEDS) and the State Energy Price and Expenditure Report 1988 (SEPER). Inconsistencies in EIA published end-use price data are examined with respect to Federal, State, and local government sales and excise taxes. Recommended actions are presented. Estimated bias in EIA's SEPER prices is discussed, with an examination of end-use taxes by various fuel types and the magnitude of bias in the SEPER series. Appendices include documentation tables, Federal and State tax tables, references and an index.

DOE/EIA-0583 One-time August $1994116 \mathrm{pp}$. NTIS Stock Number: DE94017471 NTIS Price Code: A06 GPO Stock Number: 061-003-00868-2 GPO Price: $\$ 7.00$

\section{Energy Use and Carbon Emissions: Non-OECD Countries}

Examines world energy use and carbon emissions patterns, with particular emphasis on the non-OECD countries (including the current and former centrally planned economies). The non-OECD countries, making up 84 percent of world population, has energy consumption, carbon emissions, population, and gross domestic product (GDP) growing faster (for the past 20 years) than the OECD countries. This presentation is divided into seven major sections: Section 1 provides an overview of key trends in non-OECD energy use and carbon emissions since 1970 , placing the non-OECD in a world context; Section 2 compares and contrasts energy use and carbon emissions patterns for five major non-OECD regions: 1) former Soviet Union and Eastern Europe; 2) Pacific Rim (including China); 3) Latin America; 4) Other Asia (including South Asia and the Middle East); 5) Africa (including South Africa); Sections 3-7 present total and sectoral energy use and carbon emissions data for countries within each of these five regions. An appendix presents data sources and notes. Abbreviations and acronyms are included as well.

DOE/EIA-0587 One-time December $199476 \mathrm{pp}$. NTIS Stock Number: DE95004482 NTIS Price Code: A05 GPO Stock Number: 061-003-00880-1 GPO Price: $\$ 5.50$

\section{Energy Use and Carbon Emissions: Some International Comparisons \\ Examines international comparisons and other}


energy-use patterns in the context of growing concerns about the effect of energy-related carbon emissions on global climate. The report, compiled by EIA at congressional request, presents in three sections an overview of global energy use and carbon emissions from 1970 through 1992. Section 1 compares differences in energy use and carbon emissions between OECD and non-OECD countries. Section 2 examines energy use and carbon emissions in the Group of Seven (G-7) nations (Canada, France, Germany, Italy, Japan, the United Kingdom, and the United States). Section 3 discusses sectoral energy-use patterns within the G-7 nations. An appendix lists data sources and notes.

DOE/EIA-0579 Annual March $199470 \mathrm{pp}$. NTIS Stock Number: DE94009576 NTIS Price Code: A04 GPO Stock Number: 061-003-00847-0 GPO Price: $\$ 5.50$

\section{Historical Monthly Energy Review} The Historical Monthly Energy Review (HMER) presents monthly and annual data from 1973 through 1992 on production, consumption, stocks, imports, exports, and prices of the principal energy commodities in the United States. Also included are data on international production of crude oil, consumption of petroleum products, petroleum stocks, and production of electricity from nuclear-powered facilities. This publication is a

-anion to the Monthly Energy Review (MER) in inse that the data series presented here are the same as those found in the $M E R$, also published by EIA. The $H M E R$ presents monthly data for all years from 1973 through 1992 and includes previously unpublished revisions to $M E R$ data.

DOE/EIA-0035(73-92) One-time August 1994 382 pp. NTIS Stock Number: DE94017310 NTIS Price Code: A17 GPO Stock Number: 061-003-00869-1 GPO Price: $\$ 23.00$

\section{International Energy Annual 1992}

This report presents statistics for primary energy production, consumption, trade, stocks, and reserves in more than 190 countries, dependencies, and areas of special sovereignty. The report includes information for petroleum, natural gas, coal, hydroelectric power, nuclear electric power, and conventional thermal electricity. Also included are price data for crude oil, petroleum products, natural gas, electricity, and coal in selected countries. Overall production and consumption data are given both in standard physical units that correspond to units used in other EIA publications (barrels, cubic feet, short tons, kilowatthours) and in British thermal units. Other data are given in standard physical units only. Publication began with the 1979 edition.

DOE/EIA-0219(92) Annual January 1994220 pp. NTIS Stock Number: DE94005918 NTIS Price Code: A10

\section{Monthly Energy Review}

The Monthly Energy Review presents current U.S. total energy summaries and key data series for production, consumption, stocks, imports, exports, and prices of the individual energy commodities. Most of the data series are from 1973 forward. Also included are data on the international production of crude oil, consumption of petroleum products, petroleum stocks, and production of electricity from nuclear power facilities. Appendices present thermal, metric, and other physical conversion factors. Publication began in October 1974 as a publication of the Federal Energy Administration.

DOE/EIA-0035 Monthly GPO Subscription List ID: MER GPO Subscription Price: $\$ 80.00$

\section{Performance Profiles of Major Energy Producers 1992}

Pursuant to Section 205(h)(2) of the Department of Energy Organization Act, EIA, through Form EIA-28, has collected financial information and other measures of energy-related business efforts and results for major energy companies on a uniform, segmented basis. In the calendar year reported, 23 companies filed Form EIA-28. The comparability of information across energy lines of business is unique to this reporting system. For example, petroleum activities can be compared to activities in other lines of business or nonenergy areas, and domestic activities can be contrasted to foreign activities. The 
purpose of this publication is to examine year-to-year developments in the operations of the 23 major U.S. energy-producing companies on a corporate level, by major line of energy business, by major functions within each line of business, and by geographic area. This report presents data collected on Form EIA-28 for the reporting year. Although the focus is on developments in the reporting year, important trends since 1974 are also featured. Economic performance, in financial and physical dimensions, continues to serve as a significant factor in evaluating past decisions and guiding future options in the development and supply of energy resources. The information contained in this report is intended to promote both an understanding and a critical review of the possible motivations and apparent consequences of investment decisions by some of the largest corporations in the energy industry.

DOE/EIA-0206(92) Annual January 1994152 pp. NTIS Stock Number: DE94005992 NTIS Price Code: A08 GPO Stock Number: 061-003-00842-9 GPO Price: $\$ 10.00$

\section{Profiles of Foreign Direct Investment in U.S. Energy 1992}

This report summarizes the activities in the United States by foreign-affiliated companies that own or control U.S. energy sources and supplies. This report presents the following profiles for the report year: foreign direct investment in U.S. petroleum, natural gas and coal mining; energy production, processing, distribution, and reserves of foreign-affiliated companies; financial performance and investment activity of foreign-affiliated energy companies; overseas oil and gas operations of U.S. companies; and comparisons of foreign-affiliated companies with U.S. energy companies. Publication began with the 1983 edition.

DOE/EIA-0466(92) Annual May 199448 pp. NTIS Stock Number: DE94013711 NTIS Price Code: A03 GPO Stock Number: 061-003-00853-4 GPO Price: $\$ 3.25$
61 State Energy Data Report, Consumption Estimates 1992

The State Energy Data Report presents estimates of annual energy consumption at the State and national levels by principal energy type (petroleum, natural gas, coal, and electricity) and by major economic sector (residential, commercial, industrial, transportation, and electric utility) from 1960 forward. Data are presented in both physical units and British thermal units for the current year. State rankings for total energy consumption, consumption per capita, and by individual energy commodity are presented. Included in the report are documentation describing how the estimates are made for each energy source, sources of all input data, and a summary of changes from the previous report. Publication began with the 1978 edition with consumption estimates for the years 1960 to 1978 .

DOE/EIA-0214(92) Annual May $1994530 \mathrm{pp}$. NTIS Stock Number: DE94012762 NTIS Price Code: A23 GPO Stock Number: 061-003-00854-2 GPO Price: $\$ 33.00$

\section{State Energy Price and Expenditure Report 1992}

Estimated annual energy prices and expenditures are presented for each of the 50 States, the District of Columbia, and the total United States for selected years, from 1970 forward. Data for all years from 1970 forward are available on computer-readable diskettes. Estimates are shown by energy source (coal, natural gas, petroleum products, nuclear, wood/waste at electric utilities, and electricity) and by sector (residential, commercial, industrial, transportation, and electric utility). Also given are various State rankings for total expenditures, expenditures per capita, and prices by fuel type. Documentation on the price and expenditure estimates is provided, including sources of data, methods of estimation, conversion factors, and a summary of changes since the previous report. Publication began under the title Energy Price and Expenditure Report 1970-1980.

DOE/EIA-0376(92) Annual December 1994310 pp. NTIS Stock Number: DE95004173 NTIS Price 
Code: A14 GPO Stock Number: 061-003-00881-0

GPO Price: $\$ 19.00$

\section{$63 \quad$ U.S. Energy Industry Financial Developments}

This report traces key financial trends in the U.S. energy industry by quarter. Financial data are presented for companies in two broad groups--fossil fuel producing companies and rate-regulated utilities. Companies included in each industry grouping include only the publicly traded companies whose financial data were available at the time of publication. Publication began March 1991.

DOE/EIA-0543 Quarterly GPO Subscription List ID: EIFD GPO Subscription Price: $\$ 9.00$

\section{End-Use Consumption}

\section{Commercial Buildings Characteristics 1992}

The data contained in this report are collected in the Commercial Buildings Energy Consumption Survey (CBECS). EIA conducts this national sample survey of nonresidential buildings and their energy suppliers on a triennial basis. The CBECS provides basic statistical information on the consumption of, and expenditures for, energy used in commercial buildings and their energy-related characteristics. This survey is the only source of national-level data for this kind of information. This report gives descriptions of commercial buildings at the national and Census region levels in terms of the following characteristics: building use, building size, location, energy sources, energy end uses, conservation features, heating and cooling equipment and practices, lighting equipment and practices, and roof and wall construction materials.

DOE/EIA-0246(92) Triennial April 1994460 pp. NTIS Stock Number: DE94012131 NTIS Price Code: A20 GPO Stock Number: 061-003-00850-0 GPO Price: $\$ 28.00$

\section{Energy End-Use Intensities in} Commercial Buildings

This report examines energy intensities for nine end uses: space heating, cooling, ventilation, lighting, water heating, cooking, refrigeration, office equipment, and "other miscellaneous." The objective of this EIA analysis was to increase understanding of how energy is used in commercial buildings and to identify targets for greater energy efficiency which could moderate future growth in demand.

DOE/EIA-0555(94)/2 One-time September 1994 140 pp. NTIS Stock Number: DE95000623 NTIS Price Code: A07 GPO Stock Number: 061-003-00873-9 GPO Price: $\$ 9.00$

\section{Manufacturing Energy Consumption Survey, Manufacturing Consumption of Energy 1991}

The MECS data base provides the necessary information to estimate the use of energy for heat, power, and electricity generation. The use of fuels (such as crude oil and natural gas) as raw material input to manufacturing processes is also covered in the survey. This publication presents these basic energy consumption estimates along with statistics on the cogeneration of electricity, fuel storage capabilities, and prices manufacturers paid for energy. Estimates of fuel-switching capabilities will be presented in a separate EIA report.

DOE/EIA-0512(91) Triennial December 1994 550 pp. NTIS Stock Number: DE95004721 NTIS Price Code: A23 GPO Stock Number: 061-003-00887-9 GPO Price: $\$ 34.00$

\section{Reducing Home Heating and Cooling Costs}

This report is in response to a request from the House Committee on Energy and Commerce that the Energy and Commerce that EIA undertake a neutral, unbiased analysis of the cost, safety, and health and environmental effects of the three major heating fuels: heating oil, natural gas, and electricity. The committee also asked EIA to examine the role of conservation in the choice of heating and cooling 
fuel. This report discusses ways to weatherize the home, compares the features of the three major heating and cooling fuels, and comments on the types of heating and cooling systems on the market. The report also includes a worksheet, map, and supporting cost tables that will help in the selection of a heating and/or cooling system in each of three major climates for a range of likely fuel prices and system efficiencies.

DOE/EIA-SR/EMEU/94-01 Service Report July 199436 pp. NTIS Stock Number: DE94015395 NTIS Price Code: A.03

\section{Sample Design for the Residential} Energy Consumption Survey (RECS)

The purpose of this report is to provide detailed information about the multistage area-probability sample design used for the Residential Energy Consumption Survey (RECS). It is intended as a technical report, for use by statisticians, to better understand the theory and procedures followed in the creation of the RECS sample frame.

DOE/EIA-0555(94)/1 One-time August 1994108 pp. NTIS Stock Number: DE94016448 NTIS Price Code: A06 GPO Stock Number: 061-003-00865-8 GPO Price: $\$ 6.50$

\section{Models}

\section{Distillate Market Model Documentation}

\section{Report}

The Distillate Market Model performs a short-term (6 to 9 month) forecast of demand and retail prices for distillate fuel oil in the national U.S. market. The model also calculates the end-of-month stock level. The model is used to analyze certain market behavior assumptions or market disruptions and to determine their effect on retail market price, demand, and stocks.

DOE/EIA-M056 One-time February 199428 pp. NTIS Stock Number: DE94007965 NTIS Price Code: A03

\section{Documentation of the DRI Model of} the U.S. Economy

The DRI Model represents national economic production and income corresponding to the National Income and Product Accounts published by the Department of Commerce. These forecasts of national activity extend 25 years and serve as the basis for EIA macroeconomic forecasts. EIA alters the DRI forecasts so that the energy variables included in the macroeconomic model correspond to EIA energy price forecasts.

DOE/EIA-M061 One-time February $1994 \quad 48$ pp. NTIS Stock Number: DE94008081 NTIS Price Code: A03

\section{Documentation of the Oil and Gas Supply Module (OGSM)}

The Oil and Gas Supply Module (OGSM) generates, endogenously within the National Energy Modeling System (NEMS), supply functions on which are based projected production estimates of U.S. crude oil and natural gas. OGSM encompasses domestic crude oil and natural gas supply by both conventional and nonconventional (enhanced oil recovery, and unconventional gas recovery from tight gas formations, Devonian shale, and coalbeds) recovery techniques. Crude oil and natural gas projections are further disaggregated by geographic region. OGSM projects U.S. domestic oil and gas supply for six lower 48 onshore regions, three offshore regions, and Alaska. Based on forecasted drilling expenditures and average drilling costs, exploratory and developmental drilling levels are calculated for each region and fuel type.

DOE/EIA-M063 One-time March 1994224 pp. NTIS Stock Number: DE94008739 NTIS Price Code: A10

\section{EIA Model Documentation: Petroleum Market Model of the National Energy Modeling System}

The Petroleum Market Model projects petroleum product prices and sources of supply for meeting petroleum product demand. The sources of supply include crude oil, both domestic and imported; other 
inputs including alcohols and ethers; natural gas plant liquids production; petroleum product imports; and refinery processing gain. In addition, the Petroleum Marketing Model estimates domestic refinery capacity expansion and fuel consumption. Product prices are estimated at the Census division level and much of the refining activity information is at the Petroleum Administration for Defense (PAD) district level.

DOE/EIA-M059 One-time March 1994258 pp. NTIS Stock Number: DE94008738 NTIS Price Code: A12

\section{EIA Model Documentation: World Oil Refining/Logistics/Demand Model}

The WORLD Model is a linear programming model which simulates the operation of the world petroleum industry based on user-specified assumptions regarding the time horizon and scenario of interest. The WORLD Model simulates regional effects. Insights at the level of individual countries or refinery type can be obtained but only where the model has been appropriately disaggregated.

DOE/EIA-M058 One-time April 1994270 pp. NTIS Stcck Number: DE94009790 NTIS Price Code: A12

\section{Model Documentation Report:} Commercial Sector Demand Module of the National Energy Modeling System

The Commercial Demand Module forecasts consumption of commercial sector energy by building types and nonbuilding uses of energy and by category of end use, subject to delivered prices of energy, availability of renewable sources of energy, and macroeconomic variables representing gross domestic product (GDP), employment, interest rates, and floorspace construction. Both modules estimate the equipment stock for the major end-use services, incorporating assessments of advanced technologies, including representations of renewable energy technologies, and analyses of both building shell and appliance standards.
DOE/EIA-M066/R One-time August 1994248 pp. NTIS Stock Number: DE95009456 NTIS Price Code: A11

\section{Model Documentation Report:} Macroeconomic Activity Module (MAM) of the National Energy Modeling System

The Macroeconomic Activity Module provides a set of essential macroeconomic drivers to the energy modules, a macroeconomic feedback mechanism within NEMS, and a mechanism to evaluate detailed macroeconomic and interindustry impacts associated with energy events. Key macroeconomic variables include GDP, interest rates, disposable income, and employment. Industrial drivers are calculated for 35 industrial sectors. This module is a response surface representation of the Data Resources, Inc., Quarterly Model of the U.S. Economy.

DOE/EIA-M065 One-time April 1994128 pp. NTIS Stock Number: DE94009487 NTIS Price Code: A07

\section{Model Documentation Report:} Residential Sector Demand Module of the National Energy Modeling System

The Residential Demand Module forecasts consumption of residential sector energy by housing type and end use, subject to delivered energy prices, availability of renewable sources of energy, and macroeconomic variables representing population, disposable personal income, interest rates, and housing starts.

DOE/EIA-M067 One-time April 1994212 pp. NTIS Stock Number: DE94009598 NTIS Price Code: A10

77 Model Documentation Report: Transportation Sector Model of the National Energy Modeling System

The Transportation Demand Module forecasts consumption of transportation sector fuels, including petroleum products, electricity, methanol, ethanol, and compressed natural gas by transportation mode, vehicle vintage, and size class, subject to delivered 
prices of energy fuels and macroeconomic variables representing disposable personal income, GDP, population, interest rates, and the value of output for industries in the freight sector. Fleet vehicles are represented separately to allow analysis of the Clean Air Act Amendments and other legislative proposals, and the module includes a component to explicitly assess the penetration of alternative-fuel vehicles.

DOE/EIA-M070 One-time April 1994648 pp. NTIS Stock Number: DE94009863 NTIS Price Code: A99

\section{Model Documentation: Coal Market} Module of the National Energy Modeling System

The Coal Market Module (CMM) provides annual forecasts of prices, production, and consumption of coal for the National Energy Modeling System (NEMS). The CMM has three submodules, the Coal Production Submodule (CPS), the Coal Export Submodule (CES), and the Coal Distribution Submodule (CDS). In general, the CDS integrates the supply inputs from the CPS to satisfy demands for coal from exogenous demand models. The CES forecasts annual world coal trade flows from major supply to major demand regions and provides annual forecasts of U.S. coal exports and imports for input to the NEMS Coal Distribution Submodule. Specifically, the CDS receives minemouth prices produced by the CPS, demand and other exogenous inputs from other NEMS components, including the CES, and provides delivered coal prices and quantities to the NEMS economic sectors and regions.

DOE/EIA-M060 One-time March 1994208 pp. NTIS Stock Number: DE94008737 NTIS Price Code: A10

79 Model Documentation: Electricity Market Module Load and Demand-Side Management Submodule Volume 1 Model Description

DOE/EIA-M068-A/1 One-time March 1994126

pp. NTIS Stock Number: DE94009599 NTIS Price Code: A07
79 Model Documentation: Electricity Market Module Load and Demand-Side Management Submodule Volume 2 Model Code Listing

DOE/EIA-M068-A/2 One-time March 1994100 pp. NTIS Stock Number: DE94009600 NTIS Price Code: A05

\section{Model Documentation: Electricity Market Module Electricity Capacity Planning Submodule}

DOE/EIA-M068-B One-time March 1994182 pp. NTIS Stock Number: DE94009601 NTIS Price Code: A09

79 Model Documentation: Electricity Market Module Electricity Finance and Pricing Submodule

DOE/EIA-M068-C One-time March 1994104 pp. NTIS Stock Number: DE94009602 NTIS Price Code: A06

79 Model Documentation: Electricity Market Module Electricity Fuel Dispatch Submodule

DOE/EIA-M068-D One-time March 1994174 pp. NTIS Stock Number: DE94009789 NTIS Price Code: A08

The Electricity Market Module represents generation, transmission, and pricing of electricity, subject to delivered prices for coal, petroleum products, and natural gas, costs of generation by centralized renewables, macroeconomic variables for costs of capital and domestic investment and electricity load shapes and demand. There are four primary submodules--capacity planning, fuel dispatching, finance and pricing, and load and demand-side management. Nonutility generation and transmission and trade are represented in the planning and dispatching submodules. The levelized fuel cost of uranium fuel for compliance options are explicitly represented in the capacity expansion and dispatch decisions. Both new generating technologies and renewable technologies compete directly in these decisions. The competition between utility and nonutility generation and several options for wholesale pricing are included. 
80 Model Documentation: Natural Gas Transmission and Distribution Model of the National Energy Modeling System

The Natural Gas Transmission and Distribution Model (NGTDM) represents the transmission, distribution, and pricing of natural gas. The model also includes representations of the end-use demand for natural gas, the production of domestic natural gas, and the availability of natural gas traded on the international market based on information received from other National Energy Modeling System (NEMS) models. The NGTDM determines the flow of natural gas in an aggregate, domestic pipeline network, connecting domestic and foreign supply sources with 12 demand regions. The methodology employed allows the analysis of impacts of regional capacity constraints in the interstate natural gas pipeline network and the identification of primary pipeline capacity expansion requirements. There is an explicit representation of firm and interruptible markets for natural gas transmission and distribution services, and the key components of pipeline tariffs are represented in a pricing algorithm.

DOE/EIA-M062 One-time March 1994420 pp. NTIS Stock Number: DE94008559 NTIS Price Code: A18

\section{Model Documentation: Renewable} Fuels Module of the National Energy Modeling System Appendix Model Performance

This appendix discusses performance aspects of the Renewable Fuels Module (RFM). It is intended to present the pattern of response of the RFM to typical changes in its major inputs from other NEMS modules.

DOE/EIA-M069/A One-time September 1994 12 pp. NTIS Stock Number: DE95006080 NTIS Price Code: A03

\section{Model Documentation: Renewable Fuels Module of the National Energy Modeling System}

The Renewable Fuels Module consists of six analytic submodules that represent each of the major renew- able energy resources: wood, municipal solid waste (MSW), solar energy, wind energy, geothermal energy, and alcohol fuels. Of these six, four are documented in the report: municipal solid waste, wind, solar, and biofuels. Geothermal and wood are not currently working components of NEMS. The purpose of the Renewable Fuels Module is to define the technological and cost characteristics of renewable energy technologies, and to pass these characteristics to other NEMS modules for the determination of mid-term forecasted renewable energy demand.

DOE/EIA-M069 One-time April 1994164 pp. NTIS Stock Number: DE94009962 NTIS Price Code: A08

\section{National Energy Modeling System: An Overview}

The National Energy Modeling System: An Overview (Overview) provides a summary description of NEMS. NEMS has been used to generate the forecasts of energy production, demand, imports, and prices through the year 2010 for the Annual Energy Outlook 1994 (DOE/EIA-0383(94)), released in January 1994 and the Supplement to the Energy Outlook 1994 (DOE/EIA-0554(94), released in March 1994. The Overview presents a brief description of the methodology and scope of each component modules of the NEMS.

DOE/EIA-0581 One-time May 199460 pp. NTIS Stock Number: DE94011160 NTIS Price Code: A04

\section{$84 \quad$ NEMS Industrial Module Documentation Report}

The NEMS Industrial Demand Module is a dynamic accounting model, bringing together the disparate industries and uses of energy in those industries, and putting them together in an understandable and cohesive framework. The Industrial Model generates mid-term (up to the year 2010) forecasts of industrial sector energy demand as a component of the NEMS integrated forecasting system. From the 
NEMS system, the Industrial Model receives fuel prices, employment data, and the value of output of industrial activity. Based on the value of these variables, the Industrial Model passes back to the NEMS system estimates of consumption by fuel types. The NEMS Industrial Model estimates energy consumption by energy source (fuels and feedstocks) for 26 manufacturing and 6 nonmanufacturing industries.

DOE/EIA-M064 One-time April 1994438 pp. NTIS Stock Number: DE94009486 NTIS Price Code: A19

\section{NEMS International Energy Module Model Documentation Report}

The Transportation Demand Module forecasts consumption of transportation sector fuels, including petroleum products, electricity, methanol, ethanol, and compressed natural gas by transportation mode, vehicle vintage, and size class, subject to delivered prices of energy fuels and macroeconomic variables representing disposable personal income, GDP, population, interest rates, and the value of output for industries in the freight sector. Fleet vehicles are represented separately to allow analysis of the Clean Air Act Amendments and other legislative proposals, and the module includes a component to explicitly assess the penetration of alternative-fuel vehicles.

DOE/EIA-M071 One-time April $199482 \mathrm{pp}$. NTIS Stock Number: DE94009887 NTIS Price Code: A05

\section{Propane Market Model Documentation Report}

The Propane Market Model performs a short-term (6 to 9 month) forecast of demand and price for consumer-grade propane in the national U.S. market; the model also calculates the end-of-month stock level. The model can also be used to calculate the demand and end-of-month stock level in several PAD districts. The model is used to analyze certain market behavior assumptions or market shocks and to determine their effect on market price, demand, and stocks.
DOE/EIA-M055 One-time February 199442 pp. NTIS Stock Number: DE94007964 NTIS Price Code: A03

\section{Forecasts}

\section{Annual Energy Outlook 1994}

Annual projections of energy supply, demand and prices are presented for the major fuels and electricity. The projections are based on assumptions about world oil prices, economic growth and other factors affecting energy markets. A reference case is presented which is the central forecast. To reflect the uncertainty inherent in any forecast of the future, additional cases are presented. They are based on reasonable lower and upper bounds on two key factors that affect energy trends--world oil price and the rate of economic growth. The forecasts are policy neutral--they are based on current law, and no new energy laws or regulations are introduced for any purpose. Beginning with the 1982 edition, this publication replaces the report entitled Annual Report to Congress, Volume 3: Energy Projections (DOE/EIA-0173/3). Due to a change in the naming convention, there was no 1988 issue.

DOE/EIA-0383(94) Annual January 1994196 pp. NTIS Stock Number: DE94005938 NTIS Price Code: A09 GPO Stock Number: 061-003-00841-1 GPO Price: $\$ 14.00$

\section{International Energy Outlook 1994}

This report presents the current EIA assessment of the long-term outlook for international energy markets. It emphasizes oil market developments, particularly future world oil prices and oil production potential. Also presented are projections of the consumption of oil, natural gas, coal, nuclear, and "other" energy sources for selected countries and country groups. The world oil price projections developed in this international setting are used as assumptions for analyses of the U.S. domestic energy markets. Since the U.S. energy market is affected by the international market, the method- 
ology incorporates this interaction to the extent possible. Assessments are revised and published annually. Publication began with the 1985 edition.

DOE/EIA-0484(94) Annual June $199488 \mathrm{pp}$. NTIS Stock Number: DE94014852 NTIS Price Code: A05

\section{Short-Term Energy Outlook Annual Supplement 1994}

This supplement is published once a year as a complement to the quarterly Short-Term Energy Outlook. It reviews the accuracy of the forecasts published in the last six issues of the Short-Term Energy Outlook, compares EIA's base case energy projections as published in the Short-Term Energy Outlook (DOE/EIA-0202) with recent projections made by other major forecasting groups, and examines in detail current energy topics that affect the forecasts. Publication began with the 1987 edition.

DOE/EIA-0202(94) Annual August $199476 \mathrm{pp}$. NTIS Stock Number: DE94016956 NTIS Price Code: A05 GPO Stock Number: 061-003-00866-6 GPO Price: $\$ 5.00$

\section{Short-Term Energy Outlook, Quarterly Projections}

EIA's quarterly forecasts of energy supply, demand, stocks, and prices are presented for each quarter. The forecasts are produced using the Short-Term Integrated Forecasting System, which uses two principal driving variables, a macroeconomic forecast, and world oil price assumptions. The three projections for petroleum supply and demand are based on low, middle, and high economic growth scenarios that incorporate high, middle, and low crude oil price trajectories. The tables and discussion in this volume primarily refer to the middle, or base case, scenario and to the domestic situation. Other cases examining the sensitivity of total petroleum demand to varying assumptions about prices, weather, and economic activity are presented. The petroleum outlook includes detailed projections of domestic crude oil production, motor gasoline, distillate fuel oil, residual fuel oil, other products, and inventories. Other projections include natural gas, coal, and electric power. The international petroleum situation is also discussed. Publication began October 1979.

DOE/EIA-0202 Quarterly GPO Subscription List ID: STEO GPO Subscription Price: $\$ 17.00$

\section{Supplement to the Annual Energy Outlook 1994}

The Supplement to the Annual Energy Outlook 1994 (Supplement) is a companion document to the Annual Energy Outlook 1994 (AEO94). The AEO94 presents national forecasts of energy production, demand, and prices through 2010 for five scenarios, including a reference case and four additional cases that assume higher and lower economic growth and higher and lower world oil prices. Part 1 of the Supplement presents the key quantitative assumptions underlying the $A E O 94$ projections, responding to requests by energy analysts for additional information on the forecasts. In Part II, the Supplement provides regional projections and other underlying details of the reference case projections in the $A E O 94$.

DOE/EIA-0554(94) Annual March 1994228 pp. NTIS Stock Number: DE94008626 NTIS Price Code: A11 


\section{Subject Index}

(Numbers following subject entries refer to abstract numbers)

Acid rain

Clean Air Act 44

Alternative fuels 48,49

Biomass

consumption 49

Buildings

energy consumption 64,65

Bulletin board access 4

Clean Air Act Amendments

electric utilities 44

Coal

consumption 13,14

distribution 13, 14

employment 13

exports 13,14

imports 13, 14

mine prices 13

number of mines 13

prices $13,14,39$

producers 13

production $13,14,16$

productivity 13

quality 13,39

railroad car loadings 16

reserves 13

State profiles 15

stocks 13, 14

weekly production 16

Coke

consumption 14

distribution 14

exports 14

imports 14

production 14

Commercial buildings

energy consumption 64,65

Computer models

Crude oil

Directory 3, 4

prices $28,29,33$ production $20,30,31$

production costs 17

reserves $\mathbf{3 2}$

transportation 30,31

Data collection

Electronic 11, 12

Forms 2

Degree-days 34, 58

Department of Energy 1, 10

Diskettes

directory 4

Educational materials 9

Electricity

capacity 40,47

emissions 40, 44

financial statistics $40,45,46$

fuel consumption $\mathbf{4 0 , 4 1}$

fuel costs $39,40,41$

generating capacity 40,47

generation 40,41

nonutility

generators $\mathbf{4 0}$

prices 40, 41, 42

purchases 43

sales $40-42$

transmission 43

wheeling 43

Electronic data collection 11, 12

Electronic products

directory 4

Emissions

electric generation $\mathbf{4 0 , 4 4}$

greenhouse gases $52,54,55$

Energy Education Resources 9

Energy Information Administration 1 products $4,6,7$

publications style guidelines $\mathbf{5 , 8}$

Energy Information Directory 10

Ethanol

consumption 49 
production 31,33

stocks 31,33

Fergana basin

oil and gas resources 27

Financial statistics major energy companies 63

major energy producers 59

Forecasts 87, 89-91

international 88

Foreign

investment 60

Foreign-affiliated companies $\mathbf{6 0}$

Gas fields

standardized names $\mathbf{2 6}$

largest 32

Graphs

guidelines $\mathbf{5}$

Greenhouse gases

emissions 52, 54, 55

Independent power producers $\mathbf{4 0}$

International Energy Annual 57

Manufacturers

Models

energy consumption 66

Coal Market Module 78

Commercial Sector Demand Module 74

directory $1,3,4$

Distillate Market

Model Documentation Report 69

DRI Model of the U.S. Economy 70

Electricity Market Module $\mathbf{7 9}$

Industrial Module $\mathbf{8 4}$

International Energy Module $\mathbf{8 5}$

Macroeconomic Activity Module 75

National Energy Modeling System: An Overview 83

Natural Gas Transmission and Distribution Module 80

Oil and Gas Supply Module 71

Petroleum Market Module $\mathbf{7 2}$

Propane Market Model 86

Renewable Fuels Module 81, 82

Residential Sector Demand Module 76

Transportation Sector Module 77

World Oil Refining/

Logistics/Demand Model 73
MTBE

production 31,33

stocks 31, 33

Municipal waste electricity generation 49

Natural gas

company profiles 22

consumption 23, 24

contracts 21

equipment costs 17

exports 23,24

financial performance 21

imports 23, 24

industry 22,23

industry trends 21

operating costs 17

prices 23, 24, 39

production 23, 24

production costs 17

productive capacity $\mathbf{2 5}$

regulation 21

reserves 32

storage 21,24

Nonutility generators $\mathbf{4 0}$

Nuclear energy

outlook 38

Nuclear fuel

forecasts 38

inventories 35

spent fuel $\mathbf{3 5}, \mathbf{3 8}$

storage capacity 35

uranium industry 36,37

Oil fields

standardized names 26

largest 32

Oxygenates

production 31, 33

stocks 31,33

Personal computers

directory of products 4

Petroleum products

consumption 19, 28-31, 33, 34

exports $30,31,33,34$

imports 30, 31, 33, 34

marketing 28, 29

prices 28, 29, 33, 34, 39

production $30,31,33,34$

refinery production $30,31,33$

sales $19,28,29$

stocks $30,31,33,34$ 
transportation $\mathbf{3 0}, \mathbf{3 1}$

Projections 87-91

Publications 6-8

PURPA

financial impacts 45

Refinery capacity $30,31,33$

Reformulated gasoline analysis of RFG program 18

Regulation natural gas 21

Renewable energy 49, 50

Reporting requirements 2

Reserves

coal 13

crude oil 32

natural gas 32
Residential

natural gas liquids 32

energy consumption survey 68 fuel choice 67

Solar energy

manufacturing activity $\mathbf{5 0}$

State energy consumption 61

State energy prices 62

Statistical graphs

guidelines 5

Taxes

State and local $\mathbf{5 3}$

Upcoming reports 6

Uranium industry $\mathbf{3 6 - 3 8}$

Wood energy

consumption 49 


$$
\therefore
$$




\section{Report Number Index}

DOE/EIA-0035 Monthly Energy Review

Monthly GPO Subscription List ID: MER GPO Subscription Price: $\$ 80.0058$

DOE/EIA-0035(73-92) Historical Monthly Energy Review

One-time August 1994382 pp. NTIS Stock Number: DE94017310 NTIS Price Code: A17 GPO Stock Number: 061-003-00869-1 GPO Price: $\$ 23.0056$

DOE/EIA-0095(93) Inventory of Power Plants in the United States 1993

Annual December 1994402 pp. NTIS Stock Number: DE95004720 NTIS Price Code: A18 GPO Stock Number: 061-003-00888-7 GPO Price: $\$ 24.0047$

DOE/EIA-0109 Petroleum Supply Monthly Monthly GPO Subscription List ID: PETS GPO Subscription Price: $\$ 80.0031$

DOE/EIA-0121 Quarterly Coal Report

Quarterly GPO Subscription List ID: QCR GPO Subscription Price: $\$ 26.0014$

DOE/EIA-0130 Natural Gas Monthly

Monthly GPO Subscription List ID: NSG GPO Subscription Price: $\$ 78.0024$

DOE/EIA-0131(92)/S Natural Gas Annual 1992 Supplement: Company Profiles

Annual February 1994216 pp. NTIS Stock Number: DE94006727 NTIS Price Code: A10 GPO Stock Number: 061-003-00843-7 GPO Price: $\$ 14.0022$

DOE/EIA-0131(93) Natural Gas Annual 1993 Annual October 1994264 pp. NTIS Stock Number: DE95002470 NTIS Price Code: A12 GPO Stock Number: 061-003-00879-8 GPO Price: $\$ 16.00 \quad 23$
DOE/EIA-0149(93) EIA Publications Directory 1993

Annual July 199464 pp. NTIS Stock Number: DE94015840 NTIS Price Code: A04 7

DOE/EIA-0173(93) Annual Report to Congress 1993

Annual March 1994100 pp. NTIS Stock Number: DE94009788 NTIS Price Code: A05 1

DOE/EIA-0174(93) Solar Collector Manufacturing Activity 1993

Annual August 199484 pp. NTIS Stock Number: DE94017340 NTIS Price Code: A05 GPO Stock Number: 061-003-00870-4 GPO Price: $\$ 5.50 \quad 50$

DOE/EIA-0191(93) Cost and Quality of Fuels for Electric Utility Plants 1993

Annual July 1994188 pp. NTIS Stock Number: DE94015595 NTIS Price Code: A09 GPO Stock Number: 061-003-00864-0 GPO Price: $\$ 13.0039$

DOE/EIA-0202 Short-Term Energy Outlook, Quarterly Projections

Quarterly GPO Subscription List ID: STEO GPO Subscription Price: $\$ 17.0090$

DOE/EIA-0202(94) Short-Term Energy Outlook Annual Supplement 1994

Annual August 199476 pp. NTIS Stock Number: DE94016956 NTIS Price Code: A05 GPO Stock Number: 061-003-00866-6 GPO Price: $\$ 5.0089$

DOE/EIA-0204 EIA New Releases

Bimonthly Available: NEIC 6

DOE/EIA-0205(94) Energy Information Directory Annual March 1994140 pp. NTIS Stock Number: DE94009431 NTIS Price Code: A07 10 
DOE/EIA-0206(92) Performance Profiles of Major Energy Producers 1992

Annual January 1994152 pp. NTIS Stock Number: DE94005992 NTIS Price Code: A08 GPO Stock Number: 061-003-00842-9 GPO Price: $\$ 10.0059$

DOE/EIA-0208 Weekly Petroleum Status Report Weekly GPO Subscription List ID: EWPSR GPO Subscription Price: $\$ 65.0033$

DOE/EIA-0214(92) State Energy Data Report, Consumption Estimates 1992

Annual May 1994530 pp. NTIS Stock Number: DE94012762 NTIS Price Code: A23 GPO Stock Number: 061-003-00854-2 GPO Price: $\$ 33.0061$

DOE/EIA-0216(93) U.S. Crude Oil, Natural Gas, and Natural Gas Liquids Reserves 1993 Annual Report

Annual October 1994168 pp. NTIS Stock Number: DE95002536 NTIS Price Code: A08 GPO Stock Number: 061-003-00876-3 GPO Price: $\$ 12.0032$

DOE/EIA-0218 Weekly Coal Production Weekly GPO Subscription List ID: WCPBA GPO Subscription Price: $\$ 85.0016$

DOE/EIA-0219(92) International Energy Annual 1992

Annual January 1994220 pp. NTIS Stock Number: DE94005918 NTIS Price Code: A10 57

DOE/EIA-0226 Electric Power Monthly

Monthly GPO Subscription List ID: EPM GPO Subscription Price: $\$ 87.0041$

\section{DOE/EIA-0246(92) Commercial Buildings}

Characteristics 1992

Triennial April 1994460 pp. NTIS Stock Number: DE94012131 NTIS Price Code: A20 GPO Stock Number: 061-003-00850-0 GPO Price: $\$ 28.0064$

\section{DOE/EIA-0249(94) Directory of Energy Data} Collection Forms

Annual December 199476 pp. NTIS Stock Number: DE95004329 NTIS Price Code: A05 2
DOE/EIA-0293(94) Directory of Energy Information Administration Models 1994

Annual July 1994100 pp. NTIS Stock Number: DE94014881 NTIS Price Code: A05 3

DOE/EIA-0340(93)/1 Petroleum Supply Annual 1993, Volume 1

Annual June 1994200 pp. NTIS Stock Number: DE94013720 NTIS Price Code: A09 30

DOE/EIA-0340(93)/2 Petroleum Supply Annual 1993, Volume 2

Annual June 1994608 pp. NTIS Stock Number: DE94013718 NTIS Price Code: A99 GPO Stock Number: 061-003-00856-9 GPO Price: $\$ 37.0030$

DOE/EIA-0348(92) Electric Power Annual 1992 Annual January 1994196 pp. NTIS Stock Number: DE94005401 NTIS Price Code: A09 40

DOE/EIA-0348(93) Electric Power Annual 1993 Annual December 1994198 pp. NTIS Stock Number: DE95004328 NTIS Price Code: A09 GPO Stock Number: 061-003-00884-4 GPO Price: $\$ 13.00 \quad 40$

DOE/EIA-0370(94) Oil and Gas Field Code Master List 1994

Annual December 1994454 pp. NTIS Stock Number: DE95004719 NTIS Price Code: A20 GPO Stock Number: 061-003-00890-9 GPO Price: $\$ 27.0026$

DOE/EIA-0376(92) State Energy Price and Expenditure Report 1992

Annual December 1994310 pp. NTIS Stock Number: DE95004173 NTIS Price Code: A14 GPO Stock Number: 061-003-00881-0 GPO Price: $\$ 19.0062$

DOE/EIA-0380 Petroleum Marketing Monthly Monthly GPO Subscription List ID: PMM GPO Subscription Price: $\$ 83.0029$

DOE/EIA-0383(94) Annual Energy Outlook 1994 Annual January 1994196 pp. NTIS Stock Number: DE94005938 NTIS Price Code: A09 GPO Stock Number: 061-003-00841-1 GPO Price: $\$ 14.0087$ 
DOE/EIA-0384(93) Annual Energy Review 1993 Annual July 1994412 pp. NTIS Stock Number: DE94015828 NTIS Price Code: A18 GPO Stock Number: 061-003-00863-1 GPO Price: $\$ 25.0051$

DOE/EIA-0415(94) ELA Publications Style Manual Annual July 199492 pp. Available: NEIC 8

DOE/EIA-0436(94) World Nuclear Outlook 1994 Annual December 1994144 pp. NTIS Stock Number: DE95011851 NTIS Price Code: A07 GPO Stock Number: 061-003-00883-6 GPO Price: $\$ 9.0038$

DOE/EIA-0437(92)/2 Financial Statistics of Major Publicly Owned Electric Utilities 1992

Annual January 1994544 pp. NTIS Stock Number: DE94007105 NTIS Price Code: A23 GPO Stock Number: 061-003-00845-3 GPO Price: $\$ 33.00 \quad 46$

DOE/EIA-0465(94) EIA Guidelines for Statistical Graphs

Irregular August 1994108 pp. Available: NEIC 5

DOE/EIA-0466(92) Profiles of Foreign Direct Investment in U.S. Energy 1992

Annual May 199448 pp. NTIS Stock Number: DE94013711 NTIS Price Code: A03 GPO Stock Number: 061-003-00853-4 GPO Price: $\$ 3.2560$

DOE/EIA-0478(93) Uranium Industry Annual 1993 Annual September 1994148 pp. NTIS Stock Number: DE94018625 NTIS Price Code: A07 GPO Stock Number: 061-003-00872-1 GPO Price: $\$ 10.0036$

DOE/EIA-0484(94) International Energy Outlook 1994

Annual June 199488 pp. NTIS Stock Numbẹ: DE94014852 NTIS Price Code: A05 88

DOE/EIA-0487(93) Petroleum Marketing Annual 1993

Annual December 1994428 pp. NTIS Stock Number: DE95005364 NTIS Price Code: A19 GPO Stock Number: 061-003-00892-5 GPO Price: $\$ 31.0028$
DOE/EIA-0512(91) Manufacturing Energy Consumption Survey Manufacturing Consumption of Energy 1991

Triennial December 1994550 pp. NTIS Stock Number: DE95004721 NTIS Price Code: A23 GPO Stock Number: 061-003-00887-9 GPO Price: $\$ 34.0066$

DOE/EIA-0520 International Petroleum Statistics Report

Monthly GPO Subscription List ID: IPSR GPO Subscription Price: $\$ 43.0020$

DOE/EIA-0528(94) PEDRO User Guide

One-time February 1994136 pp. NTIS Stock Number: DE95009454 NTIS Price Code: A07 11

DOE/EIA-0530 Reserves Information Gathering System User's Guide

One-time January 199480 pp. NTIS Stock Number: DE95009453 NTIS Price Code: A05 12

DOE/EIA-0531(92) Electric Trade in the United States 1992

Biennial September 1994384 pp. NTIS Stock Number: DE94019002 NTIS Price Code: A17 43

DOE/EIA-0535(93) Fuel Oil and Kerosene Sales 1993

Annual October 199460 pp. NTIS Stock Number: DE95001361 NTIS Price Code: A04 GPO Stock Number: 061-003-00877-1 GPO Price: $\$ 4.0019$

DOE/EIA-0538 Winter Fuels Report

Weekly, October - April Available: NEIC 34

DOE/EIA-0540(92) Electric Sales and Revenue 1992

Annual April 1994244 pp. NTIS Stock Number: DE94010428 NTIS Price Code: A11 42

DOE/EIA-0542(95) Natural Gas Productive Capacity for the Lower 48 States 1980 through 1995 Annual July 1994124 pp. NTIS Stock Number: DE94016592 NTIS Price Code: A06 25 
DOE/EIA-0543 U.S. Energy Industry Financial Developments

Quarterly GPO Subscription List ID: EIFD GPO Subscription Price: $\$ 9.0063$

DOE/EIA-0546(93) Energy Education Resources Annual February 199448 pp. NTIS Stock Number: DE95009455 NTIS Price Code: A03 9

DOE/EIA-0548(92) Estimates of U.S. Biomass Energy Consumption 1992

Annual May 199456 pp. NTIS Stock Number: DE94011458 NTIS Price Code: A04 GPO Stock Number: 061-003-00852-6 GPO Price: \$3.75 49

DOE/EIA-0554(94) Supplement to the Annual Energy Outlook 1994

Annual March 1994228 pp. NTIS Stock Number: DE94008626 NTIS Price Code: A11 91

DOE/EIA-0555(94)/1 Sample Design for the Residential Energy Consumption Survey (RECS)

One-time August 1994108 pp. NTIS Stock Number: DE94016448 NTIS Price Code: A06 GPO Stock Number: 061-003-00865-8 GPO Price: $\$ 6.5068$

DOE/EIA-0555(94)/2 Energy End-Use Intensities in Commercial Buildings

One-time September 1994140 pp. NTIS Stock Number: DE95000623 NTIS Price Code: A07 GPO Stock Number: 061-003-00873-9 GPO Price: $\$ 9.0065$

DOE/EIA-0560(94) Natural Gas 1994: Issues and Trends

Annual July 1994176 pp. NTIS Stock Number: DE94017190 NTIS Price Code: A09 GPO Stock Number: 061-003-00860-7 GPO Price: \$11.00 21

DOE/EIA-0569 EIA Directory of Electronic Products

Quarterly Available: NEIC 4

DOE/EIA-0570(93) Uranium Purchases Report 1993

Annual August 199412 pp. NTIS Stock Number: DE94018015 NTIS Price Code: A03 GPO Stock Number: 061-003-00867-4 GPO Price: \$1.50 37
DOE/EIA-0573 Emissions of Greenhouse Gases in the United States 1987-1992

Annual October 1994144 pp. NTIS Stock Number: DE94008247 NTIS Price Code: A07 GPO Stock Number: 061-003-00878-0 GPO Price: $\$ 9.0052$

\section{DOE/EIA-0576 State Coal Profiles}

One-time February 1994148 pp. NTIS Stock Number: DE94007086 NTIS Price Code: A07 GPO Stock Number: 061-003-00844-5 GPO Price: $\$ 10.0015$

DOE/EIA-0579 Energy Use and Carbon Emissions: Some International Comparisons

Annual March 199470 pp. NTIS Stock Number: DE94009576 NTIS Price Code: A04 GPO Stock Number: 061-003-00847-0 GPO Price: \$5.50 55

DOE/EIA-0580 Financial Impacts of Nonutility Power Purchases on Investor-Owned Electric Utilities

One-time June 1994112 pp. NTIS Stock Number: DE94013416 NTIS Price Code: A06 GPO Stock Number: 061-003-00857-7 GPO Price: $\$ 7.0045$

DOE/EIA-0581 National Energy Modeling System: An Overview

One-time May 199460 pp. NTIS Stock Number: DE94011160 NTIS Price Code: A04 83

DOE/EIA-0582 Electric Utility Phase I Acid Rain Compliance Strategies for the Clean Air Act Amendments of 1990

One-time March 1994132 pp. NTIS Stock Number: DE94009536 NTIS Price Code: A07 GPO Stock Number: 061-003-00848-8 GPO Price: $\$ 9.0044$

DOE/EIA-0583 End-Use Taxes: Current EIA Practices

One-time August 1994116 pp. NTIS Stock Number: DE94017471 NTIS Price Code: A06 GPO Stock Number: 061-003-00868-2 GPO Price: $\$ 7.0053$ 
DOE/EIA-0584(93) Coal Industry Annual 1993

Annual December 1994286 pp. NTIS Stock Number: DE95004326 NTIS Price Code: A13 GPO Stock Number: 061-003-00882-8 GPO Price: $\$ 22.0013$

DOE/EIA-0585/O Alternatives to Traditional Transportation Fuels: an Overview

One-time June 1994148 pp. NTIS Stock Number: DE94014979 NTIS Price Code: A07 GPO Stock Number: 061-003-00859-3 GPO Price: $\$ 12.0048$

DOE/EIA-0587 Energy Use and Carbon Emissions: Non-OECD Countries

One-time December 199476 pp. NTIS Stock Number: DE95004482 NTIS Price Code: A05 GPO Stock Number: 061-003-00880-1 GPO Price: $\$ 5.5054$

DOE/EIA-M055 Propane Market Model Documentation Report

One-time February 199442 pp. NTIS Stock Number: DE94007964 NTIS Price Code: A03 86

DOE/EIA-M056 Distillate Market Model Documentation Report

One-time February 199428 pp. NTIS Stock Number: DE94007965 NTIS Price Code: A03 69

DOE/EIA-M058 ELA Model Documentation: World Oil Refining/Logistics/Demand Model

One-time April 1994270 pp. NTIS Stock Number: DE94009790 NTIS Price Code: A12 73

DOE/EIA-M059 EIA Model Documentation: Petroleum Market Model of the National Energy Modeling System

One-time March 1994258 pp. NTIS Stock Number: DE94008738 NTIS Price Code: A12 72

DOE/EIA-M060 Model Documentation: Coal Market Module of the National Energy Modeling System

One-time March 1994208 pp. NTIS Stock Number: DE94008737 NTIS Price Code: A10 78
DOE/EIA-M061 Documentation of the DRI Model of the U.S. Economy

One-time February 199448 pp. NTIS Stock Number: DE94008081 NTIS Price Code: A03 70

DOE/EIA-M062 Model Documentation: Natural Gas Transmission and Distribution Model of the National Energy Modeling System

One-time March 1994420 pp. NTIS Stock Number: DE94008559 NTIS Price Code: A18 80

DOE/EIA-M063 Documentation of the Oil and Gas Supply Module (OGSM)

One-time March 1994224 pp. NTIS Stock Number: DE94008739 NTIS Price Code: A10 71

DOE/EIA-M064 NEMS Industrial Module Documentation Report

One-time April 1994438 pp. NTIS Stock Number: DE94009486 NTIS Price Code: A19 84

DOE/EIA-M065 Model Documentation Report: Macroeconomic Activity Module (MAM) of the National Energy Modeling System

One-time April 1994128 pp. NTIS Stock Number: DE94009487 NTIS Price Code: A07 75

DOE/EIA-M066/R Model Documentation Report: Commercial Sector Demand Module of the National Energy Modeling System

One-time August 1994248 pp. NTIS Stock Number: DE95009456 NTIS Price Code: A11 74

DOE/EIA-M067 Model Documentation Report: Residential Sector Demand Module of the National Energy Modeling System

One-time April 1994212 pp. NTIS Stock Number: DE94009598 NTIS Price Code: A10 76

DOE/EIA-M068-A/1 Model Documentation: Electricity Market Module Load and Demand-Side Management Submodule Volume 1 Model Description

One-time March 1994126 pp. NTIS Stock Number: DE94009599 NTIS Price Code: A07 79 
DOE/EIA-M068-A/2 Model Documentation: Electricity Market Module Load and Demand-Side Management Submodule Volume 2 Model Code Listing

One-time March 1994100 pp. NTIS Stock Number: DE94009600 NTIS Price Code: A05 79

DOE/EIA-M068-B Model Documentation: Electricity Market Module Electricity Capacity Planning Submodule

One-time March 1994182 pp. NTIS Stock Number: DE94009601 NTIS Price Code: A09 79

DOE/EIA-M068-C Model Documentation: Electricity Market Module Electricity Finance and Pricing Submodule

One-time March 1994104 pp. NTIS Stock Number: DE94009602 NTIS Price Code: A06 79

DOE/EIA-M068-D Model Documentation: Electricity Market Module Electricity Fuel Dispatch Submodule

One-time March 1994174 pp. NTIS Stock Number: DE94009789 NTIS Price Code: A08 79

DOE/EIA-M069/A Model Documentation: Renewable Fuels Module of the National Energy Modeling System Appendix Model Performance

One-time September 199412 pp. NTIS Stock Number: DE95006080 NTIS Price Code: A03 81

DOE/EIA-M069 Model Documentation: Renewable Fuels Module of the National Energy Modeling System

One-time April 1994164 pp. NTIS Stock Number: DE94009962 NTIS Price Code: A08 82

DOE/EIA-M070 Model Documentation Report: Transportation Sector Model of the National Energy Modeling System

One-time April 1994648 pp. NTIS Stock Number: DE94009863 NTIS Price Code: A99 77

DOE/EIA-M071 NEMS International Energy Module Model Documentation Report

One-time April 199482 pp. NTIS Stock Number: DE94009887 NTIS Price Code: A05 85
DOE/EIA-SR/CNEAF/94-01 Spent Nuclear Fuel Discharges from U.S. Reactors 1992

Service Report May 1994254 pp. NTIS Stock Number: DE94011195 NTIS Price Code: A12 35

DOE/EIA-SR/EMEU/94-01 Reducing Home Heating and Cooling Costs

Service Report July 199436 pp. NTIS Stock Number: DE94015395 NTIS Price Code: A03 67

DOE/EIA-SR/OOG/94-02/1 The Energy Information Administration's Assessment of Reformulated Gasoline, Volume 1

Service Report October 1994106 pp. NTIS Stock Number: DE95009451 NTIS Price Code: A06 GPO Stock Number: 061-003-00874-7 GPO Price: $\$ 6.5018$

DOE/EIA-SR/OOG/94-02/2 The Energy Information Administration's Assessment of Reformulated Gasoline, Volume 2

Service Report October 1994166 pp. NTIS Stock Number: DE95009452 NTIS Price Code: A08 GPO Stock Number: 061-003-00875-5 GPO Price: $\$ 11.0018$

DOE/EIA-SR/OOG/94-03 The Energy Information Administration's Assessment of Reformulated Gasoline: An Update

Service Report December 199444 pp. NTIS Stock Number: DE95004836 NTIS Price Code: A03 18

DOE/EIA-TR-0568 Cost and Indices for Domestic Oil and Gas Field Equipment and Production Operations 1990-1993

One-time July 1994124 pp. NTIS Stock Number: DE94015132 NTIS Price Code: A06 GPO Stock Number: 061-003-00862-3 GPO Price: $\$ 7.50 \quad 17$

DOE/EIA-TR/0575 Oil and Gas Resources of the Fergana Basin (Uzbekistan, Tadzhikistan, and Kyrgyzstan)

One-time December 1994160 pp. NTIS Stock Number: DE95004722 NTIS Price Code: A08 GPO Stock Number: 061-003-00886-1 GPO Price: $\$ 11.0027$ 


\section{Title Index}

Alternatives to Traditional Transportation Fuels: An Overview

DOE/EIA-0585/O One-time June 1994164 pp. NTIS Stock Number: DE94014979 NTIS Price Code: A08 GPO Stock Number: 061-003-00859-3 GPO Price: $\$ 12.00 \quad 48$

\section{Annual Energy Outlook 1994}

DOE/EIA-0383(94) Annual January 1994196 pp. NTIS Stock Number: DE94005938 NTIS Price Code: A09 GPO Stock Number: 061-003-00841-1 GPO Price: $\$ 14.0087$

\section{Annual Energy Review 1993}

DOE/EIA-0384(93) Annual July 1994412 pp. NTIS Stock Number: DE94015828 NTIS Price Code: A18 GPO Stock Number: 061-003-00863-1 GPO Price: $\$ 25.00 \mathbf{5 1}$

\section{Annual Report to Congress 1993}

DOE/EIA-0173(93) Annual March 1994100 pp. NTIS Stock Number: DE94009788 NTIS Price Code: A05 1

\section{Coal Industry Annual 1993}

DOE/EIA-0584(93) Annual December 1994286 pp. NTIS Stock Number: DE95004326 NTIS Price Code: A13 GPO Stock Number: 061-003-00882-8 GPO Price: $\$ 22.00 \quad 13$

\section{Commercial Buildings Characteristics 1992}

DOE/EIA-0246(92) Triennial April 1994460 pp. NTIS Stock Number: DE94012131 NTIS Price Code: A20 GPO Stock Number: 061-003-00850-0 GPO Price: $\$ 28.0064$

Cost and Indices for Domestic Oil and Gas Field Equipment and Production Operations 1990-1993 DOE/EIA-TR-0568 One-time July 1994124 pp. NTIS Stock Number: DE94015132 NTIS Price Code: A06 GPO Stock Number: 061-003-00862-3 GPO Price: $\$ 7.50 \quad 17$
Cost and Quality of Fuels for Electric Utility Plants 1993

DOE/EIA-0191(93) Annual July 1994188 pp. NTIS Stock Number: DE94015595 NTIS Price Code: A09 GPO Stock Number: 061-003-00864-0 GPO Price: $\$ 13.0039$

Directory of Energy Data Collection Forms DOE/EIA-0249(94) Annual December 199476 pp. NTIS Stock Number: DE95004329 NTIS Price Code: A05 2

Directory of Energy Information Administration Models 1994

DOE/EIA-0293(94) Annual July 1994100 pp. NTIS Stock Number: DE94014881 NTIS Price Code: A05 3

Distillate Market Model Documentation Report DOE/EIA-M056 One-time February 199428 pp. NTIS Stock Number: DE94007965 NTIS Price Code: A03 69

Documentation of the DRI Model of the U.S. Economy DOE/EIA-M061 One-time February 199448 pp. NTIS Stock Number: DE94008081 NTIS Price Code: A03 70

Documentation of the Oil and Gas Supply Module (OGSM)

DOE/EIA-M063 One-time March 1994224 pp. NTIS Stock Number: DE94008739 NTIS Price Code: A10 71

EIA Directory of Electronic Products

DOE/EIA-0569 Quarterly Available: NEIC 4

EIA Guidelines for Statistical Graphs DOE/EIA-0465(94) Irregular August 1994108 pp. Available: NEIC 5 
EIA Model Documentation: Petroleum Market Model of the National Energy Modeling System DOE/EIA-M059 One-time March 1994258 pp. NTIS Stock Number: DE94008738 NTIS Price Code: A12 72

EIA Model Documentation: World Oil Refining/Logistics/Demand Model

DOE/EIA-M058 One-time April 1994270 pp. NTIS Stock Number: DE94009790 NTIS Price Code: A12 73

\section{EIA New Releases}

DOE/EIA-0204 Bimonthly Available: NEIC 6

EIA Publications Directory 1993

DOE/EIA-0149(93) Annual July 199464 pp. NTIS Stock Number: DE94015840 NTIS Price Code: A04 7

\section{EIA Publications Style Manual}

DOE/EIA-0415(94) Annual July 199492 pp.

Available: NEIC 8

Electric Power Annual 1992

DOE/EIA-0348(92) Annual January 1994196 pp. NTIS Stock Number: DE94005401 NTIS Price Code: A09 40

\section{Electric Power Annual 1993}

DOE/EIA-0348(93) Annual December 1994198 pp. NTIS Stock Number: DE95004328 NTIS Price Code: A09 GPO Stock Number: 061-003-00884-4 GPO Price: $\$ 13.0040$

\section{Electric Power Monthly}

DOE/EIA-0226 Monthly GPO Subscription List ID: EPM GPO Subscription Price: $\$ 87.00 \mathbf{4 1}$

\section{Electric Sales and Revenue 1992}

DOE/EIA-0540(92) Annual April 1994244 pp. NTIS Stock Number: DE94010428 NTIS Price Code: A11 42

Electric Trade in the United States 1992

DOE/EIA-0531(92) Biennial September 1994384 pp. NTIS Stock Number: DE94019002 NTIS Price Code: A17 43
Electric Utility Phase I Acid Rain Compliance Strategies for the Clean Air Act Amendments of 1990

DOE/EIA-0582 One-time March 1994132 pp. NTIS Stock Number: DE94009536 NTIS Price Code: A07 GPO Stock Number: 061-003-00848-8 GPO Price: $\$ 9.0044$

\section{Emissions of Greenhouse Gases in the United} States 1987-1992

DOE/EIA-0573 Annual October $1994144 \mathrm{pp}$. NTIS Stock Number: DE94008247 NTIS Price Code: A07 GPO Stock Number: 061-003-00878-0 GPO Price: $\$ 9.00 \quad 52$

End-Use Taxes: Current EIA Practices

DOE/EIA-0583 One-time August $1994116 \mathrm{pp}$. NTIS Stock Number: DE94017471 NTIS Price Code: A06 GPO Stock Number: 061-003-00868-2 GPO Price: $\$ 7.0053$

\section{Energy Education Resources}

DOE/EIA-0546(93) Annual February 199448 pp. NTIS Stock Number: DE95009455 NTIS Price Code: A03 9

Energy End-Use Intensities in Commercial Buildings

DOE/EIA-0555(94)/2 One-time September 1994 140 pp. NTIS Stock Number: DE95000623 NTIS Price Code: A07 GPO Stock Number: 061-003-00873-9 GPO Price: $\$ 9.0065$

Energy Information Administration's Assessment of Reformulated Gasoline, The; Volume 1

DOE/EIA-SR/OOG/94-02/1 Service Report

October 1994106 pp. NTIS Stock Number: DE95009451 NTIS Price Code: A06 GPO Stock Number: 061-003-00874-7 GPO Price: \$6.50 18

Energy Information Administration's Assessment of Reformulated Gasoline, The; Volume 2

DOE/EIA-SR/OOG/94-02/2 Service Report October 1994166 pp. NTIS Stock Number: DE95009452 NTIS Price Code: A08 GPO Stock Number: 061-003-00875-5 GPO Price: \$11.00 18 
Energy Information Administration's Assessment of Reformulated Gasoline, The: An Update DOE/EIA-SR/OOG/94-03 Service Report December 199444 pp. NTIS Stock Number: DE95004836 NTIS Price Code: A03 18

Energy Information Directory

DOE/EIA-0205(94) Annual March 1994140 pp. NTIS Stock Number: DE94009431 NTIS Price Code: A07 10

Energy Use and Carbon Emissions: Non-OECD Countries

DOE/EIA-0587 One-time December 199476 pp. NTIS Stock Number: DE95004482 NTIS Price Code: A05 GPO Stock Number: 061-003-00880-1 GPO Price: $\$ 5.5054$

Energy Use and Carbon Emissions: Some International Comparisons

DOE/EIA-0579 Annual March 199470 pp. NTIS Stock Number: DE94009576 NTIS Price Code: A04 GPO Stock Number: 061-003-00847-0 GPO Price: $\$ 5.5055$

Estimates of U.S. Biomass Energy Consumption 1992

DOE/EIA-0548(92) Annual May 199456 pp. NTIS Stock Number: DE94011458 NTIS Price Code: A04 GPO Stock Number: 061-003-00852-6 GPO Price: $\$ 3.7549$

Financial Impacts of Nonutility Power Purchases on Investor-Owned Electric Utilities

DOE/EIA-0580 One-time June 1994112 pp. NTIS Stock Number: DE94013416 NTIS Price Code: A06 GPO Stock Number: 061-003-00857-7 GPO Price: $\$ 7.00 \quad \mathbf{4 5}$

Financial Statistics of Major Publicly Owned Electric Utilities 1992

DOE/EIA-0437(92)/2 Annual January 1994544 pp. NTIS Stock Number: DE94007105 NTIS Price Code: A23 GPO Stock Number: 061-003-00845-3 GPO Price: $\$ 33.0046$
Fuel Oil and Kerosene Sales 1993

DOE/EIA-0535(93) Annual October 199460 pp. NTIS Stock Number: DE95001361 NTIS Price Code: A04 GPO Stock Number: 061-003-00877-1 GPO Price: $\$ 4.0019$

Historical Monthly Energy Review DOE/EIA-0035(73-92) One-time August 1994 382 pp. NTIS Stock Number: DE94017310 NTIS Price Code: A17 GPO Stock Number: 061-003-00869-1 GPO Price: \$23.00 56

International Energy Annual 1992

DOE/EIA-0219(92) Annual January 1994220 pp. NTIS Stock Number: DE94005918 NTIS Price Code: A10 57

International Energy Outlook 1994

DOE/EIA-0484(94) Annual June 199488 pp. NTIS Stock Number: DE94014852 NTIS Price Code: A05 88

International Petroleum Statistics Report DOE/EIA-0520 Monthly GPO Subscription List ID: IPSR GPO Subscription Price: $\$ 43.0020$

Inventory of Power Plants in the United States 1993 DOE/EIA-0095(93) Annual December 1994402 pp. NTIS Stock Number: DE95004720 NTIS Price Code: A18 GPO Stock Number: 061-003-00888-7 GPO Price: $\$ 24.0047$

Manufacturing Energy Consumption Survey Manufacturing Consumption of Energy 1991

DOE/EIA-0512(91) Triennial December 1994 550 pp. NTIS Stock Number: DE95004721 NTIS Price Code: A23 GPO Stock Number: 061-003-00887-9 GPO Price: $\$ 34.0066$

Model Documentation Report: Commercial Sector Demand Module of the National Energy Modeling System

DOE/EIA-M066/R One-time August 1994248 pp. NTIS Stock Number: DE95009456 NTIS Price Code: A11 74 
Model Documentation Report: Macroeconomic Activity Module (MAM) of the National Energy Modeling System

DOE/EIA-M065 One-time April 1994128 pp. NTIS Stock Number: DE94009487 NTIS Price Code: A07 75

Model Documentation Report: Residential Sector Demand Module of the National Energy Modeling System

DOE/EIA-M067 One-time April 1994212 pp. NTIS Stock Number: DE94009598 NTIS Price Code: A10 76

Model Documentation Report: Transportation Sector Model of the National Energy Modeling System

DOE/EIA-M070 One-time April 1994648 pp. NTIS Stock Number: DE94009863 NTIS Price Code: A99 77

Model Documentation: Coal Market Module of the National Energy Modeling System

DOE/EIA-M060 One-time March 1994208 pp. NTIS Stock Number: DE94008737 NTIS Price Code: A10 78

Model Documentation: Electricity Market Module Electricity Capacity Planning Submodule

DOE/EIA-M068-B One-time March 1994182 pp. NTIS Stock Number: DE94009601 NTIS Price Code: A09 79

Model Documentation: Electricity Market Module Electricity Finance and Pricing Submodule DOE/EIA-M068-C One-time March 1994104 pp. NTIS Stock Number: DE94009602 NTIS Price Code: A06 79

Model Documentation: Electricity Market Module Electricity Fuel Dispatch Submodule

DOE/EIA-M068-D One-time March 1994174 pp. NTIS Stock Number: DE94009789 NTIS Price Code: A08 79
Model Documentation: Electricity Market Module Load and Demand-Side Management Submodule Volume 1 Model Description

DOE/EIA-M068-A/1 One-time March 1994126 pp. NTIS Stock Number: DE94009599 NTIS Price Code: A07 79

Model Documentation: Electricity Market Module Load and Demand-Side Management Submodule Volume 2 Model Code Listing

DOE/EIA-M068-A/2 One-time March 1994100 pp. NTIS Stock Number: DE94009600 NTIS Price Code: A05 79

Model Documentation: Natural Gas Transmission and Distribution Model of the National Energy Modeling System

DOE/EIA-M062 One-time March 1994420 pp. NTIS Stock Number: DE94008559 NTIS Price Code: A18 80

Model Documentation: Renewable Fuels Module of the National Energy Modeling System Appendix Model Performance

DOE/EIA-M069/A One-time September 1994 12 pp. NTIS Stock Number: DE95006080 NTIS Price Code: A03 81

Model Documentation: Renewable Fuels Module of the National Energy Modeling System

DOE/EIA-M069 One-time April 1994164 pp. NTIS Stock Number: DE94009962 NTIS Price Code: A08 82

Monthly Energy Review

DOE/EIA-0035 Monthly GPO Subscription List ID: MER GPO Subscription Price: $\$ 80.0058$

National Energy Modeling System: An Overview DOE/EIA-0581 One-time May $199460 \mathrm{pp}$. NTIS Stock Number: DE94011160 NTIS Price Code: A04 83

Natural Gas 1994: Issues and Trends DOE/EIA-0560(94) Annual July 1994176 pp. NTIS Stock Number: DE94017190 NTIS Price Code: A09 GPO Stock Number: 061-003-00860-7 GPO Price: $\$ 11.00 \quad 21$ 
Natural Gas Annual 1992 Supplement: Company Profiles

DOE/EIA-0131(92)/S Annual February 1994 216 pp. NTIS Stock Number: DE94006727 NTIS Price Code: A10 GPO Stock Number: 061-003-00843-7 GPO Price: \$14.00 22

Natural Gas Annual 1993

DOE/EIA-0131(93) Annual October 1994264 pp. NTIS Stock Number: DE95002470 NTIS Price Code: A12 GPO Stock Number: 061-003-00879-8 GPO Price: $\$ 16.00 \quad 23$

Natural Gas Monthly

DOE/EIA-0130 Monthly GPO Subscription List ID: NSG GPO Subscription Price: $\$ 78.0024$

Natural Gas Productive Capacity for the Lower 48 States 1980 through 1995

DOE/EIA-0542(95) Annual July 1994124 pp. NTIS Stock Number: DE94016592 NTIS Price Code: A06 25

NEMS Industrial Module Documentation Report DOE/EIA-M064 One-time April 1994438 pp. NTIS Stock Number: DE94009486 NTIS Price Code: A19 84

NEMS International Energy Module Model Documentation Report

DOE/EIA-M071 One-time April 199482 pp. NTIS Stock Number: DE94009887 NTIS Price Code: A05 85

Oil and Gas Field Code Master List 1994

DOE/EIA-0370(94) Annual December 1994454 pp. NTIS Stock Number: DE95004719 NTIS Price Code: A20 GPO Stock Number: 061-003-00890-9 GPO Price: $\$ 27.00 \quad 26$

Oil and Gas Resources of the Fergana Basin (Uzbekistan, Tadzhikistan, and Kyrgyzstan)

DOE/EIA-TR/0575 One-time December 1994 160 pp. NTIS Stock Number: DE95004722 NTIS Price Code: A08 GPO Stock Number: 061-003-00886-1 GPO Price: \$11.00 27
PEDRO User Guide

DOE/EIA-0528(94) One-time February 1994 136 pp. NTIS Stock Number: DE95009454 NTIS Price Code: A07 11

Performance Profiles of Major Energy Producers 1992

DOE/EIA-0206(92) Annual January 1994152 pp. NTIS Stock Number: DE94005992 NTIS Price Code: A08 GPO Stock Number: 061-003-00842-9 GPO Price: $\$ 10.0059$

\section{Petroleum Marketing Annual 1993}

DOE/EIA-0487(93) Annual December 1994428 pp. NTIS Stock Number: DE95005364 NTIS Price Code: A19 GPO Stock Number: 061-003-00892-5 GPO Price: $\$ 31.0028$

Petroleum Marketing Monthly

DOE/EIA-0380 Monthly GPO Subscription List ID: PMM GPO Subscription Price: \$83.00 29

Petroleum Supply Annual 1993, Volume 1 DOE/EIA-0340(93)/1 Annual June 1994200 pp. NTIS Stock Number: DE94013720 NTIS Price Code: A09 $\mathbf{3 0}$

Petroleum Supply Annual 1993, Volume 2 DOE/EIA-0340(93)/2 Annual June 1994608 pp. NTIS Stock Number: DE94013718 NTIS Price Code: A99 GPO Stock Number: 061-003-00856-9 GPO Price: $\$ 37.0030$

Petroleum Supply Monthly

DOE/EIA-0109 Monthly GPO Subscription List ID: PETS GPO Subscription Price: $\$ 80.0031$

Profiles of Foreign Direct Investment in U.S. Energy 1992

DOE/EIA-0466(92) Annual May 199448 pp. NTIS Stock Number: DE94013711 NTIS Price Code: A03 GPO Stock Number: 061-003-00853-4 GPO Price: $\$ 3.2560$

Propane Market Model Documentation Report DOE/EIA-M055 One-time February 199442 pp. NTIS Stock Number: DE94007964 NTIS Price Code: A03 86 
Quarterly Coal Report

DOE/EIA-0121 Quarterly GPO Subscription List ID: QCR GPO Subscription Price: $\$ 26.0014$

Reducing Home Heating and Cooling Costs DOE/EIA-SR/EMEU/94-01 Service Report July 199436 pp. NTIS Stock Number: DE94015395 NTIS Price Code: A03 67

Reserves Information Gathering System User's Guide

DOE/EIA-0530 One-time January 199480 pp. NTIS Stock Number: DE95009453 NTIS Price Code: A05 12

Sample Design for the Residential Energy Consumption Survey (RECS)

DOE/EIA-0555(94)/1 One-time August 1994108 pp. NTIS Stock Number: DE94016448 NTIS Price Code: A06 GPO Stock Number: 061-003-00865-8 GPO Price: $\$ 6.5068$

Short-Term Energy Outlook Annual Supplement 1994

DOE/EIA-0202(94) Annual August $199476 \mathrm{pp}$. NTIS Stock Number: DE94016956 NTIS Price Code: A05 GPO Stock Number: 061-003-00866-6 GPO Price: $\$ 5.0089$

Short-Term Energy Outlook, Quarterly Projections DOE/EIA-0202 Quarterly GPO Subscription List ID: STEO GPO Subscription Price: $\$ 17.0090$

Solar Collector Manufacturing Activity 1993 DOE/EIA-0174(93) Annual August 199484 pp. NTIS Stock Number: DE94017340 NTIS Price Code: A05 GPO Stock Number: 061-003-00870-4 GPO Price: $\$ 5.50 \quad 50$

Spent Nuclear Fuel Discharges from U.S. Reactors 1992

DOE/EIA-SR/CNEAF/94-01 Service Report May 1994254 pp. NTIS Stock Number: DE94011195 NTIS Price Code: A12 35

State Coal Profiles

DOE/EIA-0576 One-time February 1994148 pp. NTIS Stock Number: DE94007086 NTIS Price Code: A07 GPO Stock Number: 061-003-00844-5 GPO Price: $\$ 10.00 \quad 15$
State Energy Data Report, Consumption Estimates 1992

DOE/EIA-0214(92) Annual May 1994530 pp. NTIS Stock Number: DE94012762 NTIS Price Code: A23 GPO Stock Number: 061-003-00854-2 GPO Price: $\$ 33.0061$

State Energy Price and Expenditure Report 1992 DOE/EIA-0376(92) Annual December 1994310 pp. NTIS Stock Number: DE95004173 NTIS Price Code: A14 GPO Stock Number: 061-003-00881-0 GPO Price: $\$ 19.00 \mathbf{6 2}$

Supplement to the Annual Energy Outlook 1994 DOE/EIA-0554(94) Annual March 1994228 pp. NTIS Stock Number: DE94008626 NTIS Price Code: A11 91

U.S. Crude Oil, Natural Gas, and Natural Gas Liquids Reserves 1993 Annual Report

DOE/EIA-0216(93) Annual October 1994168 pp. NTIS Stock Number: DE95002536 NTIS Price Code: A08 GPO Stock Number: 061-003-00876-3 GPO Price: $\$ 12.0032$

\section{U.S. Energy Industry Financial Developments}

DOE/EIA-0543 Quarterly GPO Subscription List ID: EIFD GPO Subscription Price: $\$ 9.0063$

Uranium Industry Annual 1993

DOE/EIA-0478(93) Annual September 1994148 pp. NTIS Stock Number: DE94018625 NTIS Price Code: A07 GPO Stock Number: 061-003-00872-1 GPO Price: $\$ 10.0036$

\section{Uranium Purchases Report 1993}

DOE/EIA-0570(93) Annual August 199412 pp. NTIS Stock Number: DE94018015 NTIS Price Code: A03 GPO Stock Number: 061-003-00867-4 GPO Price: $\$ 1.5037$

Weekly Coal Production DOE/EIA-0218 Weekly GPO Subscription List ID: WCPBA GPO Subscription Price: $\$ 85.0016$

\section{Weekly Petroleum Status Report}

DOE/EIA-0208 Weekly GPO Subscription List ID: EWPSR GPO Subscription Price: $\$ 65.0033$ 
Winter Fuels Report

DOE/EIA-0538

Weekly, October - April
World Nuclear Outlook 1994

DOE/EIA-0436(94) Annual December 1994144 pp. NTIS Stock Number: DE95011851 NTIS Price

Code: A07 GPO Stock Number: 061-003-00883-6 GPO Price: $\$ 9.0038$ 


\section{Energy Information Administration's Products and Services}

\section{Energy Information Directory}

The Energy Information Directory is a free, annual directory which lists and describes Federal and State Government offices and trade associations involved in energy matters. The purpose is to assist energy information users in locating sources of energy information other than the National Energy Information Center (NEIC). Use Order Form C to be placed on the mailing list or to receive the latest issue.

\section{EIA New Releases}

This is a free bimonthly, current awareness newsletter which lists and describes recently released EIA publications. It also informs readers of new EIA products and services. Use Order Form $\mathrm{C}$ to be placed on the mailing list or to receive the latest issue.

\section{EIA Directory of Electronic Products}

The EIA Directory of Electronic Products is a free, quarterly directory which lists and describes machine-readable data files and computer models. The data files and models are available on magnetic tapes. Selected data files/models are available on diskette for IBM-compatible personal computers. For each product listed in the directory, a detailed abstract is provided which describes the data pub- lished. Use Order Form $C$ to be placed on the mailing list or to receive the latest issue.

\section{Directory of Energy Data Collection Forms}

This directory is designed to provide an overview of EIA's energy information collection program. Each form listed in the directory contains an abstract with the following information: the general energy source(s) and function(s) covered by the form; the general categories of respondents; the frequency of collection; the public law and, if applicable, regulations associated with the collection; the requirement of reporting; the name and phone number of the collection manager; and the publications resulting from the data collection. The directory, as well as single blank copies of the forms listed, is available free of charge from NEIC. Use Order Form $\mathrm{C}$ to be placed on the mailing list or to receive the latest issue.

\section{Directory of Energy Information Administration Models}

This directory contains descriptions of all active EIA models. Included for each model are the title, acronym, purpose, and type, followed by more detailed information on characteristics, uses, and requirements. Thirty-seven models are included in the 1994 directory, which is available free from NEIC. Use Order Form $C$ to be placed on the mailing list or to receive the latest issue. 


\section{Energy Information Sheets}

NEIC has a publication containing 23 information sheets on various aspects of coal, electricity, petroleum, and natural gas. Some sheets explain renewable types of energy, nuclear fuel, and the meaning of such terms as "degree-days" and "British thermal units." Written for the layman, the publication is free. Subjects are as follows:

Crude Oil Production

Crude Oil and Petroleum Products Prices

Petroleum Product Consumption

Petroleum Reserves

Propane

Reformulated Gasoline

Coal Production

Coal Prices

Coal Demand

Coal Reserves

Natural Gas Production

Natural Gas Prices

Natural Gas Consumption

Natural Gas Reserves

Electricity Generation

Electricity Prices

Electricity Sales

Electricity Capability

Nuclear Power Generation

Renewable Energy

Degree-Days

Apples, Oranges, and Btu

Residential Uses of Energy

Use Order Form $C$ to receive the latest issue.

\section{Energy Information for School Children}

Energy Education Resources is a compilation of sources of free or low-cost energy-related educational materials geared for primary school and secondary school students and educators. It contains names, addresses, and telephone numbers of the publishers, and a brief description of the coverage. This is available free from NEIC. Use Order Form C.

\section{Feature Articles}

Feature articles are short dissertations on key energy topics, written by the EIA staff and published in selected EIA periodicals. NEIC reprints these articles and keeps current ones in stock for distribution. They are free of charge. Current articles are listed in EIA New Releases. Call NEIC for further information.

\section{Services for the Hearing Impaired}

NEIC has installed a telecommunications system for people who are deaf or hard of hearing (TTY). This device makes it possible for the hearing impaired to request and receive complete assistance from NEIC. The number for TTY is (202) $586-1181$.

\section{Electronic Publishing System (EPUB)}

EIA maintains the Electronic Publishing System (EPUB) to allow the general public to electronically access many of EIA's statistical reports and other selected energy data. These files may be downloaded to a user's system free of charge. EPUB is a menu-driven, bulletin-board-type system with extensive on-line help capabilities that can be accessed free of charge 24 hours a day. Dial-up access is available by using a terminal or PC with an asynchronous modem. Internet access is available via File Transfer Protocol (FTP) or Gopher.

Users can access EPUB to list data reports to their terminal screen, download reports to their printer, or download reports to their PC or to a diskette. Most data are presented in files that are in ASCII format, although there may be additional versions of the same files in compressed, software-specific format (e.g. Lotus 1-2-3).

Dial-up access users must provide the following information to their communications software in order to successfully access the EPUB system: 
COMMUNICATIONS PARAMETERS

$\begin{array}{ll}\text { Baud Rate: } & 300-19,200 \text { bps } \\ \text { Data Bits: } & 8 \\ \text { Stop Bits: } & 1 \\ \text { Parity: } & \text { None } \\ \text { Duplex: } & \text { Full } \\ \text { Terminal } & \text { Type:(e.g. } \\ \text { etc.) } & \end{array}$

\section{EPUB SYSTEM TELEPHONE NUMBERS}

EPUB access: (202) 586-2557 (24 hours a day)

Communications or technical assistance: (202) 5868959 (8 a.m. to 5 p.m., M-F, eastern time)

Data questions: (202) 586-8800 (9 a.m. to 5 p.m., eastern time, M-F); TTY: (202) 586-1181 (9 a.m. to 5 p.m., eastern time, M-F)

\section{INTERNET ACCESS TO EPUB}

Internet access to EPUB system is now in place, though construction is ongoing. Access over Internet is available via File Transfer Protocol (FTP) and Gopher.

The FTP access address is: ftp.eia.doe.gov. The Gopher access address is: gopher.eia.doe.gov.

Once connection to the system has been made, some users may find that the menu-driven instructions and the on-line help capabilities will provide enough information to effectively use EPUB. If additional help is needed, please contact:

National Energy Information Center, EI-231 Energy Information Administration

Forrestal Building, Room 1F-048

Washington, DC 20585

(202) $586-8800$

TTY: (202) 586-1181

The following files are accessible on the EPUB system:

\section{Coal, Nuclear, \& Alternate Fuels}

Weekly Coal Production Report (WCPR). Statistics on U.S. production of bituminous coal and lignite and the production of Pennsylvania anthracite are provided for each of the 2 most recent weeks, for a corresponding week in the previous year, and for the prior 52-week period and the corresponding period in the previous year, with percentage changes. Total U.S. production, and the number of railroad cars loaded are also reported.

Updated on Fridays at 5 p.m.

Quarterly Coal Report (QSCR). Statistics on U.S. coal production, consumption, exports, imports, and stocks is provided by quarter for the most recent quarter and quarterly for previous years. Consumption and stocks are reported by end-use sector, and annual production trends are reported by State.

Updated 60 days after the end of the quarter.

\section{Oil \& Gas}

Winter Fuels Natural Gas (WFRG). Statistics on natural gas in underground storage for the 5 most recent months are reported. Data are on base and working gas in storage; change from the same period in the previous year; and injections, withdrawals, and net of injections/withdrawals.

Updated every Thursday at 5 p.m., October through April.

Winter Fuels Pricing (WFRM). Statistics on residential and wholesale prices of heating oil and propane, by region and State, are reported in weekly time-series.

Updated every Thursday at 5 p.m., October through April.

Winter Fuels Propane (WFRP). Statistics on propane production, imports, and stocks, monthly and weekly, for the total U.S. and for Petroleum Administration for Defense Districts I, II, and III. Updated every Thursday at 5 p.m., October through April.

Winter Fuels Distillate (WFRD). Statistics on distillate production, imports, and stocks, monthly and weekly, for the total U.S. and for Petroleum Administration for Defense Districts I, II, and III. Updated every Thursday at 5 p.m., October through April.

Winter Fuels Highlights (WFRH). The most recent distillate, propane, natural gas, and pricing highlights from the Winter Fuels Report are 
reported. Includes weekly and monthly data, and covers production, consumption, imports, and stocks.

Updated every Thursday at 5 p.m., October through April.

Winter Fuels Report (WFR). The most recent weekly data from the highlights, distillate, propane, and pricing sections of the Winter Fuels Report are displayed.

Updated every Thursday at 5 p.m., October through April.

Oxygenate Data (OXYDATA). Statistics by month on fuel ethanol, methyl tertiary butyl ether (MTBE), and methanol production, stocks, and amount blended into motor gasoline are reported. Data are by PAD district and for the total United States.

Updated approximately 15 working days after the end of the month.

Weekly Petroleum Status Report (WPSR). The latest U.S. petroleum balance sheet and the last 5 weeks of Weekly Petroleum Status Report data are reported. Data include domestic crude oil production, petroleum imports and exports, crude input to refineries, petroleum products supplied for consumption, and petroleum stocks.

Updated on Wednesdays (Thursdays in event of holidays) at 9 a.m.

PSM State Stocks (STKS). The most recent month's data on refinery, bulk terminal, and natural gas plant stocks of selected petroleum products (product specific) by PAD district and State are reported.

Updated on the 20th of the month.

Petroleum Marketing Report (PMMR). Statistical data for the most current 3 months and the reference month 1 year ago on crude oil and petroleum product prices and sales volumes are reported. Data are for the United States and by PAD district.

Updated on the 20th of the month.

Weekly On-Highway Diesel Prices (DIESLPRC). Weekly data by U.S. average and PAD district of the retail, on-highway, self service, cash price (including taxes) of diesel fuel. Prices are historical back to March 21, 1994.

Updated on Monday at 5:00 p.m.

Weekly Retail Gasoline Prices (GASOLINE).

Weekly data by U.S. average and PAD district of retail, unleaded regular, self service cash price (including taxes) for motor gasoline.

Updated on Tuesday at 5:00 p.m.

Natural Gas Monthly (NGMR). Data for the most recent 5 months on natural gas supply and disposition and prices are reported. Data are at the national level for supply and disposition, consumption by consuming sector, and price; and by State and end-use sector for deliveries and price to end-users.

Updated on the 20th of the month.

\section{Energy Forecasts}

Short-Term Energy Outlook (STEO). Quarterly forecast for the next four quarters of the U.S. energy supply and demand summary; forecast assumptions; international petroleum balance; energy prices; domestic supply and disposition of petroleum in low, mid, and high world oil price scenarios; and supply and disposition of natural gas, coal, and electricity for a mid world oil price are reported.

Updated 60 days after the end of the quarter.

Short-Term Energy Model (STM95QN.ZIP).

The complete package (in compressed format) of EIA's Short-Term Energy Model, which is used to forecast supply and prices of major fuels 18 months into the future. The model allows users to access all forecast information used by EIA to produce its short-term projections, to change data and forecasts to percentages and graphs, and to revise forecast assumptions and recalculate the model. Updated each quarter.

Annual Energy Outlook. The five projection cases from the Annual Energy Outlook 1994 are presented. These tables are the tables given in Appendices A-E of the publication. 


\section{Monthly Energy Review}

Monthly Energy Review (MER). Statistics on current U.S. total energy summaries and key data series for production, consumption, stocks, imports, exports, and prices of the individual energy commodities are presented. Most of the data series are from 1973 forward. Also included are data on the international production of crude oil, consumption of petroleum products, petroleum stocks, and production of electricity from nuclear power facilities. All data tables from the Monthly. Energy Review, including the Btu conversion factors, are included.

Updated the last week of the month.

\section{EIA Press Releases}

The full text of the latest press releases from the Energy Information Administration is included.

Updated as new press releases are issued.

\section{EIA Publications Directory}

Publications Directory (PUBDIR.EXE). The text of the EIA Publications Directory includes abstracts of the publications produced during 1993.

Updated annually when the publication is released.

New Releases (NEWREL). The text of the most current bimonthly newsletter which lists and describes recently released EIA publications.

Updated bimonthly.

\section{Upcoming Analyses and Publications}

Contains listings and scheduled date of issuance of upcoming publications and analysis reports from the Energy Information Administration.

Updated quarterly/as needed.

\section{Monthly Petroleum Imports}

Contains monthly data for the current reporting year, and annualized data for the prior reporting year on crude oil and petroleum product imports into the United States. Data include the name of the importer of record, commodity imported, port of entry, quantity imported, percent sulfur by weight, API gravity, and processing company and location. Updated monthly.

\section{Financial Reporting System}

Contains tables from EIA's Performance Profiles of Major Energy Producers on operating statistics, profit ratios, balance sheet, cash flows, income taxes, U.S. well completions, development and production expenses, refining statistics, research and development expenses, and coal reserves and production. Data are aggregated for all companies reporting under EIA's Financial Reporting System.

Updated annually.

\section{Energy Information Contacts}

Contains names and telephone numbers of EIA subject matter contacts for inquiries on EIA data, forecasts, and statistical standards and methods. Also contains text of the Energy Information Directory. Updated annually/as needed.

\section{Monthly Energy Review Features File}

List of all feature articles published in the Monthly Energy Review and the text of the latest article to have been published.

Updated monthly/as needed.

\section{End-Use Consumption Surveys File}

Text of feature articles and tables of results from EIA's energy consumption surveys. Updated as new articles are published.

\section{Electric Power Monthly}

Summary electric utility statistics at the national and State level on net generation, fossil fuel consump- 
tion, fossil fuel stocks, sales, revenue, average revenue per kilowatthour sold, and fossil fuel receipts for the most recent month, the corresponding month for the previous year, and for the prior month are reported. Generation, consumption, receipts, and stocks are fuel specific; and sales, revenue, and average revenue are specific to end-use sector. Forty-four of the 64 publication tables are included.

Updated on the 1st of the month.

\section{Petroleum Supply Monthly}

Statistical data on the U.S. daily average supply and disposition of petroleum; crude oil production by state and PAD district; imports of petroleum into the United States by country of origin; and petroleum stocks by PAD district are reported. Data are mostly for the most recent month. Approximately 80 report files, taken from the Petroleum Supply Monthly.

Updated between the 23rd and 26th of the month.

\section{Comprehensive Oil \& Gas Information Source}

The Comprehensive Oil \& Gas Information Source (COGIS) lists up to 10 years of oil and gas data collected by EIA. Virtually all of the data are taken from issues of EIA's Petroleum Supply Monthly, Petroleum Marketing Monthly, Natural Gas Monthly, and the Weekly Petroleum Status Report. Available data include petroleum and natural gas reserves, production, imports, exports, refining, distribution, consumption, transportation, inventories, and prices.

COGIS is a cooperative project between EIA and the Department of Commerce, and resides on Commerce's Economic Bulletin Board, which is accessible through Internet and via modem. For more information about accessing files on the Economic Bulletin Board, contact the Department of Commerce at (202) 482-1986.

\section{Internet}

Inquiries can now be sent to NEIC on the Internet. NEIC's E-Mail address is: infoctr@eia.doe.gov.

PC users must provide the following information in their E-Mail message: your name, affiliation and address, daytime telephone number, fax number, and E-Mail address. NEIC will choose the best medium to respond to your inquiry as quickly as possible.

Selected EIA information products are accessible through the Internet, though construction is ongoing. Access over Internet is available via File Transfer Protocol (FTP), Gopher, and the World Wide Web (WWW).

The FTP access address is: ftp.eia.doe.gov.

The Gopher access address is: gopher.eia.doe.gov. The EIA Home Page World Wide Web address is:

http://www.eia.doe.gov or

http://apollo.osti.gov/html/eia/eiahome.html.

For more information about the EIA Home Page contact the National Energy Information Center at (202) $586-8800$ or via Internet E-Mail at infoctr@eia.doe.gov.

Also available on the EIA Home Page are: EIA New Releases; an "Energy Data Information Contacts" listing; selected feature articles and press releases; and a natural gas and oil contact information listing. EIA will continue to place most upcoming feature articles, press releases, and other items of interest onto this system.

The data and information contained in EIA's Electronic Publishing System (EPUB), detailed above, are accessible through the FTP and Gopher addresses listed here.

Selected information in the form of database files from EIA's coal production and electric utility surveys are also accessible via FTP and Gopher at the addresses listed above. These database files are mostly unaggregated, company specific data. These 
files are also available via Internet access to the FedWorld electronic bulletin board operated by the National Technical Information Service (NTIS). This bulletin board can be accessed via Internet FTP address:

192.239.92.205

or by Internet telnet address:

192.239.93.3

There is no charge for downloading files from the "Energy Library" section of this bulletin board.

\section{How to Order from the U.S. Government Printing Office}

Current periodicals are available on an annual subscription basis from the Government Printing Office (GPO). Current annual and one-time reports are also available from GPO.

\section{How to Order}

Type or print your name and address, purchase order number (if any), Superintendent of Documents deposit account number (if applicable), VISA or MasterCard number (if applicable), and expiration date in proper places on the order form found elsewhere in this catalog. Please include your daytime telephone number. When ordering single copy publications, type or print the stock number (the number preceded by "S/N" with each annotation), quantity, title, price, and total payment enclosed. When ordering subscriptions, type or print the list ID, title, price each, and total payment enclosed. Please use the enclosed order form, or if it's missing, you can mail your order and payment to Superintendent of Documents, P.O. Box 371954, Pittsburgh, PA 15250-7954.

\section{Phone/Fax Orders}

Publications may be ordered from the Order Desk at (202) 512-1800 between 8 a.m. and 4 p.m., eastern time, Monday through Friday. To fax your order use (202) 512-2250, 24 hours a day, 7 days a week.

\section{How to Remit}

Payment in advance of shipment is required. Your check or money order should be made payable to the Superintendent of Documents. Your order may also be charged to a VISA, MasterCard, or prepaid Superintendent of Documents deposit account. If a credit card is used, please be sure to include the date of expiration. Postage stamps and currency are not acceptable forms of payment. Remittance must accompany all orders (do not send order and remittance separately). Orders received without remittance will not be processed.

\section{Delivery}

\section{Publications}

Delivery within the United States takes approximately 4 weeks. Delivery to a foreign address takes approximately 6-8 weeks.

\section{Subscriptions}

Delivery time for subscriptions varies according to the frequency that a particular subscription is issued. Customers will receive the next available subscription issue after their order is received.

Delivery of daily or weekly subscriptions takes approximately 4 weeks for the first issue, and all subsequent issues will be delivered according to the issue frequency (e.g., daily, weekly). Other subscriptions are issued either monthly, bimonthly, quarterly, semi-annually, or irregularly and can take 2-6 months for delivery of the first issue. An acknowledgement card is sent to all customers directly after their subscription order is processed simply to let them know that they will receive the next available issue released for their subscription order.

All subscriptions are for one year unless otherwise noted. Subscribers will be notified in ample time to renew. For orders being shipped outside of the United States, see International Orders, page 49. 


\section{Bookstore Orders in the Washington, DC, Area}

Some recent issues of EIA publications may be ordered and picked up from Washington, DC, bookstores. Please call the McPherson Bookstore (202-653-5075) located at 1510 H Street, N.W.

(9 a.m. to $4: 30$ p.m. eastern time) or the Main GPO Bookstore (202-512-0132) located at 710 North Capitol Street, N.W. (8 a.m. to 4 p.m., eastern time) to see if your selected book is available. Bookstores are open Monday through Friday and accept cash, check made out to the Superintendent of Documents, VISA, MasterCard, or a prepaid Superintendent of Documents Account.

\section{Shipping}

The Superintendent of Documents pays for normal shipping; however, arrangements can be made to bill you for special shipping needs, such as Federal Express, United Parcel Service (UPS), first class, and airmail services, which are available for an additional charge. Orders are mailed fourth class unless otherwise requested. Please contact GPO at (202) 512-1800 for rate information. Please indicate on your order if you desire special postage.

\section{Federal Express}

Federal Express service is available for publication orders only. Requests for this service are made by calling (202) 512-1800, Monday through Friday, between 8 a.m. and 4 p.m., eastern time. An additional charge will be applied to the publication price for this service. Delivery guarantees are determined based on the date and time the order is submitted and the shipping address.

\section{Customer Service}

Occasionally, errors may occur in the processing of orders. Should you find an error in your order, please write to the Superintendent of Documents. All claims must be submitted within 6 months.
PLEASE DO NOT RETURN PUBLICATIONS UNLESS SO NOTIFIED. Publications will not be accepted for return, for exchange, or for credit unless an error was made by the Superintendent of Documents in filling your order. All sales are final.

\section{Inquiries}

Please wait at least 6 weeks for publications and 6 weeks for subscriptions before inquiring about your order. For inquiries on subscriptions, write to Subscription Service Section, U.S. Government Printing Office, Stop: SSOM, Washington, DC 20402. Call (202) 512-1806 or fax (202) 512-2168 for subscription inquiries. For inquiries on publications write to Publication Service Section, U.S. Government Printing Office, Stop: SSOP, Washington, DC 20402. Call (202) 512-1803 or fax (202) 512-2168 for inquiries concerning publication orders.

\section{Bookdealers}

Designated bookdealers are authorized a 25-percent discount on the domestic price of any publication or subscription ordered when delivered to the dealer's normal place of business. This rule applies to single as well as multiple copies of a publication, except on items specifically designated "no discount allowed." No discounts will be allowed when the publication, pamphlet, periodical, or subscription service is mailed to a third party (unless in quantities of 100 or more), or on those periodicals or subscription services that fall into a special pricing category. The maximum discount allowed is 25 percent.

\section{Orders for 100 or More Copies}

Any customer ordering 100 or more copies of a single subscription or other publication for delivery to a single destination will be allowed a 25 -percent discount on the domestic price of the item (except those items specifically designated "no discount allowed"). 


\section{Deposit Accounts}

A deposit account may be established by sending a minimum of $\$ 50$ and receiving a unique deposit account number, which can be used to charge future purchases. Blank order forms are provided and monthly statements are mailed to customers with active deposit accounts. Orders will be accepted on any deposit account if sufficient funds are available in the account. For more information, please write:

Superintendent of Documents

U.S. Government Printing Office

Deposit Accounts Section

Washington, DC 20402

(202)512-0822

\section{International Orders}

International orders require a special handling charge which amounts to an additional 25-percent of the current domestic price. This charge covers the special handling required by customs and international mailing regulations. All international orders are shipped via surface mail unless the customer specifically requests air mail shipping. If you desire air mail service for your shipment, please contact the Superintendent of Documents in advance by letter, telephone (202)512-1800, Telex TWX 710 822-9413) ANSWERBACK USGPO WSH, or fax (202)512-2250 for air mail postage rates. All back ordered items and supplemental issues of basic or supplement subscription services are sent by surface mail.

Note: GPO cannot accept checks drawn on Canadian banks for less than U.S. \$4. Orders sent directly to GPO must be in English. GPO cannot accept foreign currency, checks on foreign banks, or postage stamps. A minimum of 10 weeks for delivery should be allowed.

\section{Government Printing Office Priority Announcement Service}

In response to numerous requests on how to be informed when annual or one-time publications are available for sale, GPO provides a Priority Announcement Service for all EIA annual and onetime reports available from GPO. This is a FREE service.

All energy titles are included in Priority Announcement List N-562. Individuals may be added to the mailing list for this category and, when a new publication is available for sale, a notice will be sent with an order form. Please include the code number, $\mathrm{N}-562$, when requesting this service. To be placed on the mailing list contact:

Superintendent of Documents U.S. Government Printing Office Mail List Branch (Stop: SSOM) Washington, DC 20402

\section{U.S. Government Depository Libraries}

U.S. Government Depository Libraries are congressionally designated libraries throughout the United States which automatically receive some or all U.S. Government publications. Their Government documents collection is available free for use by the general public. Most states have one regional depository which carries all Government documents. The remaining 1,350 depository libraries carry selected Government documents. Most full-service public libraries will borrow EIA and other Government documents from depository libraries through interlibrary loan. To find your nearest depository library contact your local library.

\section{How to Order from the National Technical Information Service}

The National Technical Information Service (NTIS) maintains microfiche of most EIA publications; paper copies can be produced from the microfiche in most cases. Customers ordering from NTIS have a number of options from which to choose. 


\section{Reaching NTIS}

Telephone orders may be placed by calling (703) 487-4650. The NTIS telephone sales desk is available between $8: 30$ a.m. and 5 p.m., eastern time. (TTY: 703-487-4639).

\section{Mail Orders}

Send orders to: NTIS, 5285 Port Royal Road, Springfield, VA 22161. Do not mail RUSH orders.

\section{Fax Orders}

Fax: (703) 321-8547. For assistance, call (703) 487-4679.

Faxing your order? Get order forms designed to speed your order. Call (703) $487-4650$ and ask for NTIS PROFA.

Ordering Through On-line Services

DIALOG, OCLC, ORBIT, and STN allow you to order NTIS technical reports on-line. Inquiries should be directed to:

DIALOG, 1-(800)-334-2564

OCLC, $1-(800)-848-5800$

(in Ohio) $1-(800)-848-8286$

ORBIT, 1-(800)-456-7248

(in Virginia: (703) 442-0900

STN, 1-(800)-848-6533

(in Ohio) 1-(800)-848-6538

\section{E-Mail Orders}

Order through the Internet 24 hours a day: orders@ntis.fedworld.gov.

If you have an NTIS deposit account, please include the number when ordering. If you plan to order by credit card, and are concerned about Internet security, you may register your credit card at NTIS to avoid sending your account number with each order. Simply call (703) 487-4682, leave your card number and expiration date, and we will automatically charge your card when your E-Mail order is processed.

As with any order, please include the product number, title, quantity desired, and media type for each item, telephone number, or E-Mail address, as well as a full shipping address.

\section{How to Pay}

Credit Cards

American Express, MasterCard, or VISA are accepted.

\section{Check or Money Order}

Payable to NTIS in U.S. dollars drawn on a U.S. bank, an international bank with a U.S. address on the check, or a Canadian bank.

\section{NTIS Deposit Account}

This convenient debit account service makes it easy to order from NTIS. The advantages include:

- An account number to simplify all ordering

- Monthly statements with detailed transactions and routing information

- A free subscription to NTIS Newsline, issued quarterly.

To open an account, call the NTIS Customer Accounts Division at (703) $487-4064$, or write or call NTIS and request NTIS PR33, Open An NTIS Account.

\section{Billing Charge}

If prepayment is not made, please add $\$ 7.50$ to the total order to cover the billing charge. This option is available for U.S., Canada, and Mexico orders only. 


\section{Special Delivery Options}

\section{RUSH Service}

Technical report RUSH orders are generally shipped the next business day by express courier in the United States or by Air Mail to Canada, Mexico, and other countries. Add $\$ 15$ for each item in your order. For customers outside the United States, Canada, and Mexico, add $\$ 25$. To order, call 1-(800)-553-NTIS. Outside the United States, call (703) $487-4650$.

\section{Computer Product RUSH Service}

Computer product RUSH orders are charged the same as technical report RUSH orders if the computer product is in stock.

If the diskettes or tapes need to be produced, they are processed by NTIS within 3-5 business days at the following rates:

- For diskettes, add $\$ 25$ per title. RUSH fees for tapes range from $\$ 50$ to $\$ 100$,

- Outside the United States, Canada, and Mexico: for diskettes, add $\$ 35$ per title. RUSH fees for tapes range from $\$ 60$ to $\$ 130$.

To order, call 1-(800)-553-NTIS. Outside the United States, call (703) 487-4650. RUSH service is available by telephone only.

\section{Pickup Service}

Orders may be picked up at the NTIS Bookstore at 5285 Port Royal Road, Springfield, Virginia (I-495, Exit 5 West) on weekdays between 8:30 a.m. and 5 p.m. eastern time. The handling fee is waived. Customers may also use the references at the Bookstore to identify needed information.

Air Mail

Orders are shipped surface mail to countries other than the United States, unless air mail or courier service is requested.

Shipping paper copy reports by air mail is $\$ 4$ per report to Canada and Mexico and $\$ 8$ per report to other countries.
Shipping microfiche is $\$ 1$ per report to Canada and Mexico and $\$ 1.25$ per report to other countries.

International orders for computer products are shipped by air courier at no additional fee.

\section{Additional Information}

\section{Order Numbers}

All NTIS orders are processed using the NTIS product number. Always use it to speed your request. It is provided in each NTIS information citation.

If you do not have the product number, NTIS can provide it if you have the complete title of the report. Write or call the NTIS Research Services Branch at (703) 487-4780. A limit of three titles will be identified by telephone at one time. Help is available from 8:30 a.m. to 5 p.m., eastern time.

Prices

Prices are usually identified with a price code. To convert price codes to a dollar amount, see pg. . An out-of-print surcharge may apply to certain titles acquired by NTIS more than three years prior to the current calendar year. Please call NTIS to verify price. To get additional copies of the price schedule, call (703) 487-4650 and ask for NTIS PR360-3 for the United States, Canada, and Mexico. For other countries, ask for NTIS PR-360-4.

\section{Handling Fee}

Fee does not apply to RUSH service, Selected Research in Microfiche (SRIM), subscriptions, standing orders, and pickup orders. Documents downloaded directly from FedWorld ${ }^{\circledR}$ are exempt while all other documents ordered from FedWorld ${ }^{\text {(e) }}$ are subject to the handling fee. Rates are as follows:

Value of Order

Handling Fee

$\$ 10.00$ or less

$\$ 2.00$

$\$ 10.01-\$ 50.00$

$\$ 4.00$

$\$ 50.01-\$ 100.00$

$\$ 6.00$

Over $\$ 100.00$

$\$ 8.00$

Add $\$ 2$ to above for orders sent outside of the U.S., Canada, and Mexico. 
Postage and Shipping

Orders are sent first class or equivalent in the United States. Orders to other countries are shipped surface mail unless air mail or courier service is requested.

Tracing an Order

If you have questions about your order, write or call the NTIS Customer Service Department at (703) 487-4660 between 8:30 a.m. and 5 p.m., eastern time.

\section{Discounts for Technical Reports}

A 25-percent discount is available for most documents if five or more copies of a single title are ordered at the same time and shipped to the same address. For discounts on more than 100 copies, call (703) $487-4650$.

\section{Refund Policy}

Although NTIS cannot accept returns for credit or refund, they will gladly replace any item you requested if they made an error in filling your order, if the item was defective, or if you received it in damaged condition. Just call the NTIS Customer Service Department at (703) 487-4660.

\section{Holiday Openings}

The NTIS Sales Desk, Bookstore, and Customer Service Department are open from 8:30 a.m. to 5 p.m., eastern time, and on four Federal holidays: Martin Luther King, Jr.'s Birthday, Presidents Day, Columbus Day, and Veterans Day.

\section{NTIS Price Schedules 1995}

NTIS generally uses price codes to indicate the cost of items sold. The following schedules convert these codes into actual 1995 prices for customers in the United States, Canada, and Mexico only and are subject to change. For the most recent schedule, write or call (703) 487-4650 and request NTIS PR-360-3. Customers in other countries should ask for NTIS PR-360-4.
Price Codes for Microfiche and Printed Reports

Note: "A" codes apply to standard prices. Price Code

Price-\$

A01*

$\mathrm{A} 02 *$

$\mathrm{A} 03$

17.50

A04 through A05

19.50

A06 through A09

27.00

36.50

A10 through A13

44.50

52.00

A18 through A21

61.00

A22 through A25

A99

Contact NTIS

for price

*A01 for standard microfiche is $\$ 9.00$

$*$ A02 for standard microfiche is $\$ 12.50$

\section{How to Order from the National Energy Information Center}

Subscriptions and current in-stock single issues are available free of charge from NEIC for the following users: Government, news media, public and academic libraries, and EIA's survey respondents.

Call (202) 586-8800 (or TTY: (202) 586-1181) for more information or use Order Form $\mathrm{C}$. This form is also used for change of address, for deleting a name from the NEIC mailing list, or for ordering free publications.

\section{How to Use Order Forms}

To order EIA publications, first identify the distribution agency: the Government Printing Office (GPO), the National Technical Information Service 
(NTIS), or the National Energy Information Center (NEIC).

Please note separate order forms, marked A, B, and C. To ensure expedient processing of your order(s), it is imperative to use the appropriate order form. General instructions for the use of the order forms follow; more specific instructions are included on the form.

Use Order Form A for single issues of EIA publications and for EIA publications available on a subscription basis from GPO. When placing your order, always specify the publication title and the GPO Stock Number or the GPO List ID. Include either payment in full, a charge card number, or deposit account information. Send the completed order form to GPO at the address on the order form. Or you may call (202) 512-1800 between 8 a.m. and 4 p.m., eastern time, Monday through Friday or fax (202) 512-2250, 24 hours a day, seven days a week.

Use Order Form B for ordering EIA publications available from NTIS. Send the completed form to NTIS at the address on the order form. Always include either payment in full, a charge card number, or deposit account information with your order. Or you may call (703) $487-4650$ or fax (703) 321-8547.

Use Order Form $\mathrm{C}$ for ordering free publications, free subscriptions, and for NEIC mail list changes/additions. Send the completed form to NEIC using the address on the order form.

\section{NOTICE}

Prices of EIA publications sold by the U.S. Government Printing Office (GPO) and the National Technical Information Service (NTIS) are subject to change without notice.

When EIA publications are discontinued and consolidated into other reports, the individuals who received copies of the terminated publication through the EIA mailing list are automatically placed on the mailing list for the new publication. Subscribers to discontinued, paid publications through GPO are generally sent refunds for any balances remaining on their subscription. For further information about paid subscriptions, please contact GPO at (202) 512-1800. 
Figure 1. Order Form A: GPO Order Form

Order Processing Code:

* 7639

Charge your order:
It's easy!

Fax your orders (202) 512-2250

Publications

Phone your orders (202) 512-1800

\begin{tabular}{|c|c|c|c|c|}
\hline Qty. & Stock Number & Title & $\begin{array}{c}\text { Price } \\
\text { Each }\end{array}$ & $\begin{array}{l}\text { Total } \\
\text { Price }\end{array}$ \\
\hline & & & & \\
\hline & & & & \\
\hline & & & & \\
\hline & & & & \\
\hline & & & & \\
\hline & & & & \\
\hline
\end{tabular}

\section{Subscriptions}

\begin{tabular}{|c|c|c|c|c|}
\hline Qty. & (List ID) & Title & $\begin{array}{c}\text { Price } \\
\text { Each }\end{array}$ & $\begin{array}{c}\text { Total } \\
\text { Price }\end{array}$ \\
\hline & & & & \\
\hline & & & & \\
\hline & & & & \\
\hline & & & & \\
\hline
\end{tabular}

The; total cost of my order is $s$ Prices include regular shippping and handling and is subject to change.

\begin{tabular}{ll}
\hline Company or personal name & (Please type or print) \\
\hline Additional address/attention line & \\
\hline Street address
\end{tabular}

City, State, Zip code

Daytime phone including area code

Purchase order number (optional)
For privacy protection, check the box below:

$\square$ Do not make my name available to other mailers Check method of payment:

$\square$ Check payable to Superintendent of Documents

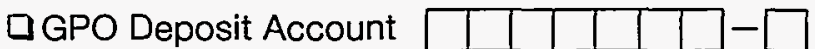
$\square$ VISA $\square$ MasterCard

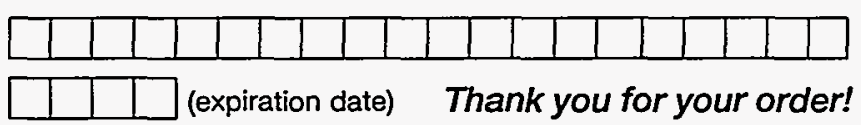

Authorizing signature $3 / 95$

Mail To: Superintendent of Documents P.O. Box 371954, Pittsburgh, PA 15250-7954

Important: Please be sure to include this completed order form with your remittance. 

Figure 2. Order Form B: NTIS Order Form

\section{U.S. DEPARTMENT OF COMMERCE TECHNOLOGY ADMINISTRATION \\ ORDER FORM DIS}

\begin{tabular}{|c|c|c|}
\hline 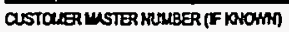 & & |OATE \\
\hline \multicolumn{3}{|l|}{ ATERTOWWUE } \\
\hline ORGAHENTOA & \multicolumn{2}{|c|}{ 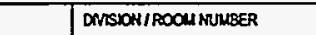 } \\
\hline \multicolumn{3}{|l|}{ STFEAT ADORESS } \\
\hline $\mathrm{cm}$ & STATE & $Z P C O O E$ \\
\hline PREONACE, TSPRTORY & & FCREGH POSTAL COOE \\
\hline \multicolumn{3}{|l|}{ courrar } \\
\hline PHOHEMLESR & FAX MULUEER & \\
\hline
\end{tabular}

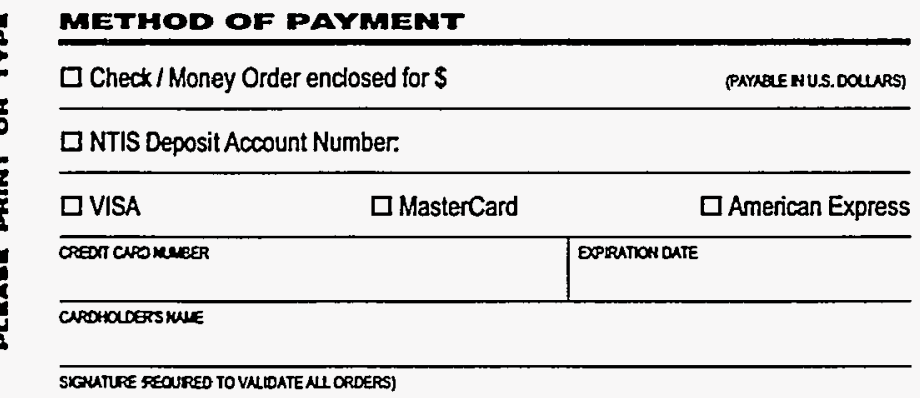

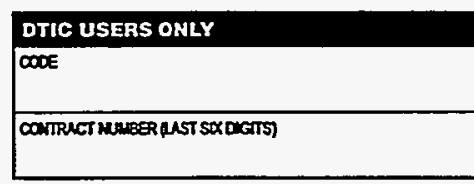

ORDER EY PHONE (EviTE UH TME) 8:30 am - 5:00 p. Eastem Time, $M-F$. Sales Destc (703) 487.4650 TDD (hearng impared only): (703) 487-4639 OFDER BY FAX 24 hours 7 days a week (703) 321-8547 To verify recespt of tax call (703) 487-4679 $7: 00 \mathrm{am}-5: 00 \mathrm{pm}$. Eastem Time, $M-F$. OADER BY MALL Hational Technical hitormation Service 5285 Port Royal Road Soringfield. VA 22161 RUSH SERVICE (DO NOT WV RUSH ORDERS) 1-800-553-NTS RUSH sernce avatable for additional fee. FEDwondo Phease cas for comect information: (703) 487-4608. BLL ME iU.S. Carada. and Hexico only.) DONOT USE THLS FORH. NTIS will ctadly bit your order, for an additional fee of 57.50. A request to be billed must be on a purchase order or company lettertead. An authorizing signature, contact rame, ano telephone number strould be induded with this request Requests may be maied or faxed.

\begin{tabular}{|c|c|}
\hline \multicolumn{2}{|c|}{ NTIS HANDLING FEE } \\
\hline Value of Order & Handling Fee \\
\hline $\begin{array}{l}\$ 10.00 \text { or less } \\
\$ 10.01-\$ 50.00 \\
\$ 50.01-\$ 100.00 \\
\text { Over } \$ 100.00\end{array}$ & $\begin{array}{r}\$ 2.00 \\
\$ \\
\$ 4.00 \\
\$ \\
\$ \\
\$ \\
\$\end{array}$ \\
\hline
\end{tabular}

Add $\$ 200$ to handling fee for orders sent outside the United States. Canada, and Mexco.

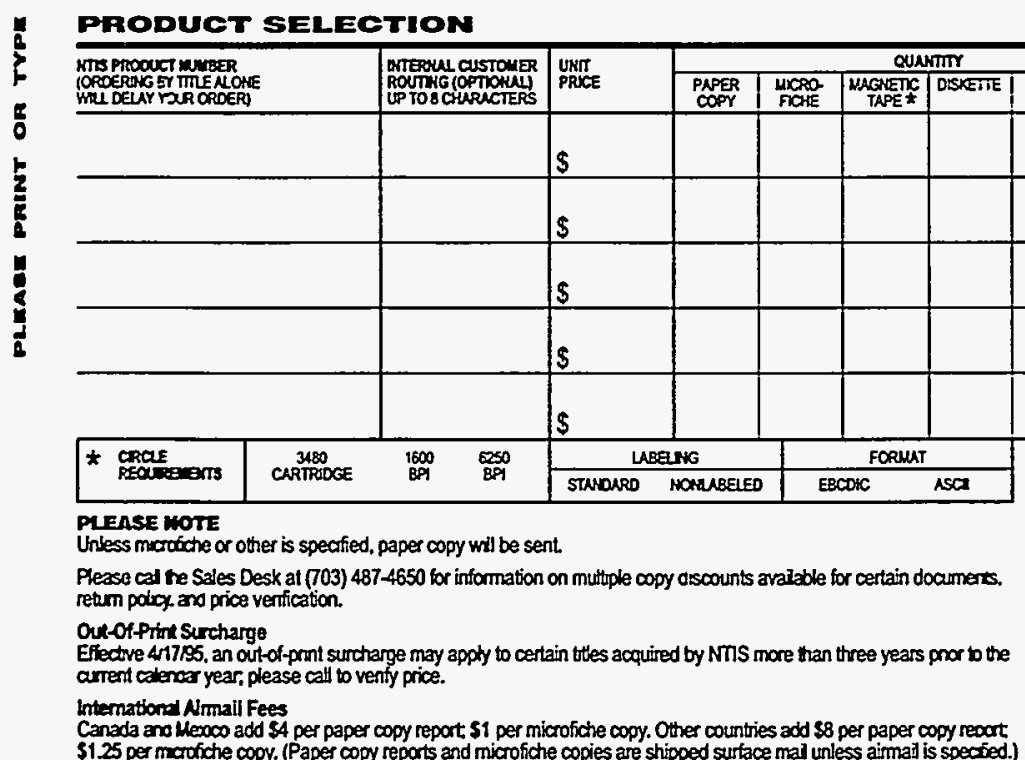

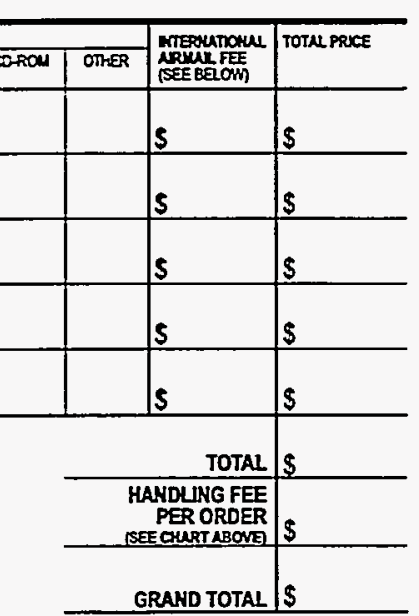

Thene soce for youer arderl Prices are subject to change.

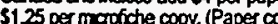

All previous versions of this form are obsolete. 
Figure 3. Order Form C: NEIC Order Form

\section{NEIC Orders}

\section{NATIONAL ENERGY INFORMATION CENTER ORDER FORM}

TO ORDER FREE PUBLICATIONS--TO NOTIFY NEIC OF CHANGE OF ADDRESS

--TO CANCEL A MAILING LIST PUBLICATION

Mail to: National Energy Information Center, El-231

Energy Information Administration

Room 1F-048, Forrestal Building

Washington, DC 20585

Name

Business Affiliation

Address

City and State

Zip Code

$(1)$

Phone number with area code
Mail List I.D. Number (Found in upper left corner of your mailing label.)

Change of address.

$\square$ Add name to mailing list for free publication(s) as listed below.

$\square$ Take name off mailing list for publication(s) as listed below.

$\square$ Free publication(s) as listed below. 